


The Institute has attempted to obtain the best original copy available for filming. Features of this copy which may be bibliographically unique, which may alter any of the images in the reproduction, or which may significantly change the usual method of filming, are checked below.

\section{Coloured covers/}

Couverture de couleur

\section{Covers damaged/}

Couverture endommagée

Covers restored and/or laminated/

Couverture restaurée et/ou pelliculée

Cover title missing/

Le titre de couverture manque

\section{Coloured maps/}

Cartes géographiques en couleur

Coloured ink (i.e. other than blue or black)/

Encre de couleur (i.e. autre que bleve ou noire)

Coloured plates and/or illustrations/

Planches et/ou illustrations on couleur

Bound with other material/

Relib avec d'autres documents

Tight binding may cause shedows or distortion along interior margin/

La reliure serrén pout couser de l'ombre ou de lo distortion le long de la marge intórieure

Blank leeves added during restoration may eppear within the text. Whenever posslble, these have been omitted from filming/

II se peut que certaines pages blenches ajoutbes lors d'une restauration epparaissent dans le texte. mais, lorsque cele stait possible, ces pages n'ont pas été fllmóes.

\section{Additional commente:}

Commentaires supplementaires
L'Institut a microfilmé le meilleur exemplaire qu'il lui a été possible de se procurer. Les détails de cet exemplaire qui sont peut-être uniques du point de vue bibliographique, qui peuvent modifier une image reproduite, ou qui peuvent exiger une modification dans la méthode normale de filmage sont indiqués ci-dessous.

Coloured pages/

Pages de couleur

Pages damaged/

Pages endommagées

Pages restored and/or laminated/

Pages restaurées et/ou pelliculées

Pages discoloured, stained or foxed/

Pages décolorées, tachetées ou piquées

Pages deteched/

Pages détachées

Showthrough/

Transparence

Quality of print varies/

Qualite intgale de l'impression

Includes supplementary material/

Comprand du matériel supplémentaire

Only edition available/

Seule edition disponible

Pages wholly or partially obscured by errata slips, tissues, etc., have been refilmed to ensure the best possible image/ Les peges totelement ou partiellement obscurcies per un feuillet d'errata, une pelure, etc. ont eté filmés nouveau de façon a obtenir la meilleure image possible.
The in possib of the filming

Origin beginn the las: sion, 9 othar 4 first pe sion. \& or illus

The la: shall $c$ TINUE which

Maps, differe entirel beginn right a require motho

This item is filmed at the reduction ratio checked below/ Ce document est fllmb au taux de reduction indiqu ci-dessous.

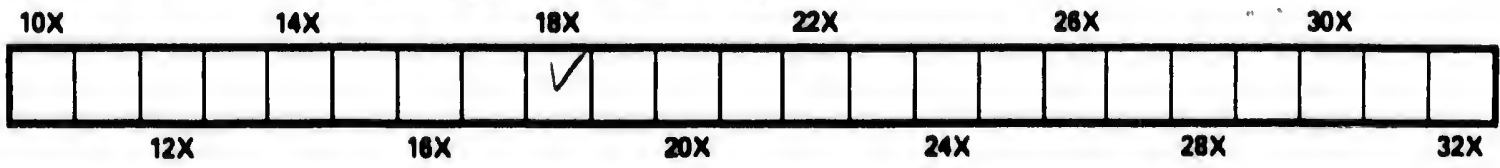


The copy filmed here has been reproduced thanks to the generosity of:

Metropolitan Toronto Library Canadian History Department

The images appearing here are the best quality possible considering the condition and legibility of the original copy and in keeping with the filming contract specifications.

Original copies in printsd peper covers are filmed beginning with the front cover and ending on the last page with a printed or lllustrated impresslon, or the back cover when eppropriate. All other original coples are filmed beginning on the first page with a printed or lllustrated impression, and ending on the last page with a printed or Illustrated impression.

The last recorded frame on each microfiche shall contain the symbol $\rightarrow$ Imeaning "CONTINUED"), or the symbol $\nabla$ (meaning "END"), whichever applies.

Maps, plates, charts, etc., may be fllmed at different reduction ratios. Those too large to be entirely included in one exposure are filmed beginning in the upper left hand corner, left to right and top to bottom, as many frames as requlred. The following diagrams lllustrate the mothod:
L'exemplaire filmé fut reproduit gráce a la gónórosité de:

Metropolitan Toronto Library Canadian History Dopartment

Les images suivantes ont 6té reproduites avec le plus grand soin, compte tenu de la condition et de la netteté de l'exemplaire filme, et en conformité avec les conditions du contrat de filmage.

Les exemplair 38 originaux dont la couverture en papier est Imprimée sont filmos en commençant par le premier plat et en terminant soit par la derniebre page qui comporte une empreinte d'impression ou d'illustration, soit par le second plat, selon le cas. Tous les autres exemplaires originaux sont filmés on commençant par la premiere page qui comporte une empreinte d'impression ou d'illustration et en terminant par la derniere page qui comporte une telle empreinte.

Un des symboles sulvants apparaitra sur la derniere image de chaque microflche, solon lo ces: le symbole $\rightarrow$ signifie "A SUIVRE", le symbole $\nabla$ signifie "FIN".

Les cartes, planches, tableaux, etc., peuvent etre filmos a des taux de réduction différants. Lorsque le document est trop grend pour etre reproduit on un seul clichs, il est fllmb a partir de l'angle supérieur gauche, de gauche al droite, et de haut en bas, en prenent le nombre d'Images nócessaire. Les diagrammes suivants Illustrent la móthode.
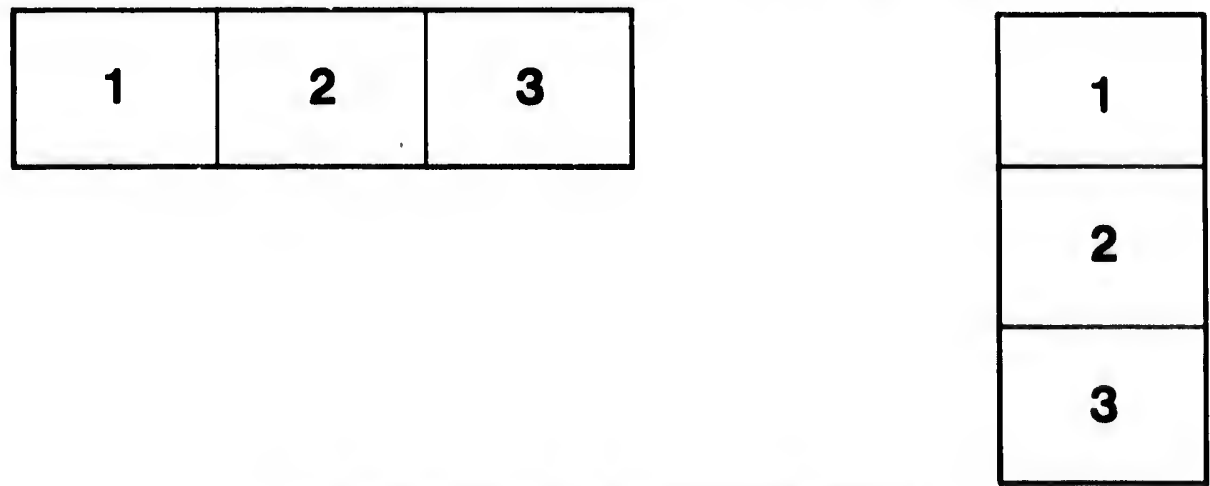

\begin{tabular}{|l|l|l|}
\hline 1 & 2 & 3 \\
\hline 4 & 5 & 6 \\
\hline
\end{tabular}




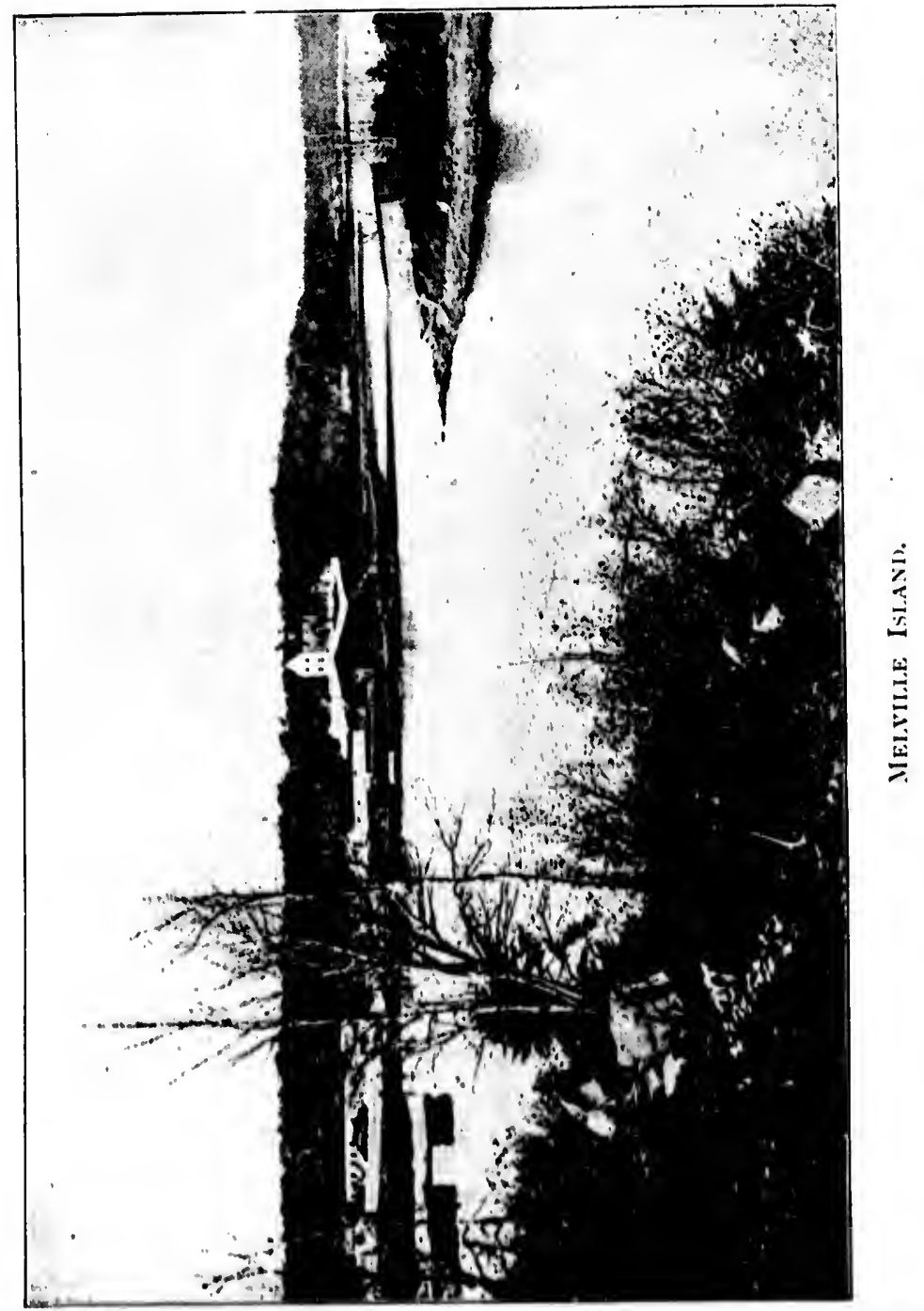

$\mathrm{N}$ 


\title{
NATURE IN ACADIE
}

BY

H. K. SWANN

Author of "The Birds of London," \&sc.

\author{
Lolloon \\ JOHN BALE \& SONS \\ OXFORI) HOUSE \\ GREAT TITCIFIELD STREET, OXFORD STREET, W. \\ 1895
}


Lit this bc sense narrat togeth of wha prose but nc Nei doings author not jor It $v$ has be is pro interes

$$
\begin{aligned}
& B 2 \\
& 117.16 \\
& 58.1
\end{aligned}
$$




\section{PREFACE.}

LitTLE apology is necessary for the appearance of this book; inasmuch as it is not intended to be in any sense a scientific work. It is more strictly the simple narrative of a Nature-lover's first voyage westward, together with some few attempts at the word-picturing of what he saw during his sojourn in Acadia, which in prose is rendered Nova Scotia-a sweet name, maybe, but not so sweet as the elder one.

Neither is the book intended to be concerned with the doings of men, and it will be found, indeed, that the author has studiously ignored the subject. One need not journey three thousand miles to study human Nature.

It will be found, however, that some little attention has been paid to ornithology, and in this connection it is probable that the work may contain something of interest to the naturalist as well as the Nature-lover.

$$
\text { H. K. S. }
$$




\section{H. D. THOREAU.}

Many long years have fled Since thou wast goneGone! aye, yet still not dead ; Thou livest on!

In every zephyr breeze

That wanders lone,

Whispering among the trees

With listless tone-

Striking on harpstrings free

Sweet sylvan chords,

While every list'ning tree

Breathless applauds-

In all the songs of birds,

Mid woodlands lone,

I hear thy noble words

Sadder of tone.

E'er through their music throng,

It seems to me,

Whispers of heavenly song

That speak of thee.

And in the rippling streams

That softly sing,

Thy voice for ever seems

Through them to ring.

*

*

*

See where the winding creek

Pierces the land

In it clear silver streak,

Woods on each hand! 
There as the wavelets swell At break of day,

A message strange they tell Idly at play-

Burthen so free and far, So deep and wide,

Lisped to the truant star Caught by the tide-

Message of Spring and Youth, Decay and Death ;

Echoes of secret truth That the gay south wind saith Under its breath.

And e'en the birches slight Along the shore, That from the waters bright Their secrets store,

Speak their young modest mind With whispers soft,

That an eavesdropping wind Carries aloft Unto me oft-.

Bids me to list the song, Sung low and faint By winds that sigh along Sad in complaint ;

Plaint of a sorrow rare In whispered tone;

Murmurs and sighings their Meaning unknown;

Babbled by leaves and air And brooklets lone. 


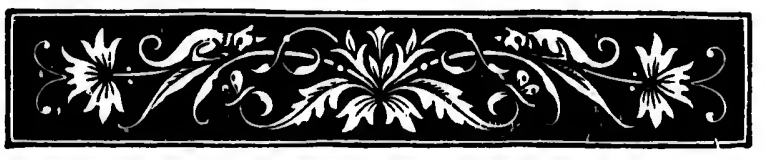

\section{NATURE IN ACADIE.}

\section{CHAPTER I.}

Have the elder races halted?

Do they droop and end their lesson, wearied over there beyond the seas? We take up the task eternal, and the burden and the lesson,

Pioneers ! $\mathrm{O}$ pioneers !-Whitman.

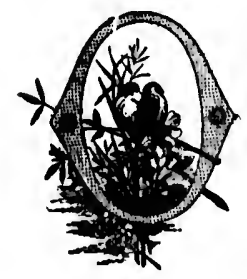

$\mathrm{H}$ for a larger field-the solitude of the forest, or the silence of the prairie, where one can roam at will and lose the rush of life! Such was the hope that found me on the deck of an outward bound liner in the docks at Liverpool on this 29th day of September, buoyed with the hope of the newer world across the Atlantic. Long years had I thirsted for the vast solitary woods, the clear sparkling lakes and silent hills of that great new land, and now at last came the moment of departure.

Clamour and confusion reign supreme. The deck of the great steamer is crowded with passengers taking a last view of the old country, which they a:e leaving, perhaps. for many years, possibly for ever! Before we are clear of the docks night succeeds to the calm glory 
of the autumn evening, and when we are fairly out in the Mersey the upper deck rapidly becomes deserted. Gradually the town is left behind, and the rows of lights on either shore grow fewer and fainter, giving place to night, still and dark, broken only by the screech of an occasionai steamer and the regular thud of the engines. The stars are now peering down upon the murky blackness of the river; the sea-breeze freshens, and I retire below, soon to be lulled to sleep by the gentle rolling of the vessel and the regular "swish" of the waves against her sides.

The next morning I was on deck soon after daybreak, the weather being fine, but rather hazy, and the sea just a trifle "choppy." We were passing through the Irish Sea the greater part of the day, but although I was on deck until night I observed hardly any birds; there being but a few gannets and a small number of the curious Manx shearwaters, while once a lesser blackbacked gull passed us.

We arrived at Queenstown in the small hours of the morning, leaving again before daybreak, and until about mid-day the south-west coast of Ireland was in view at no great distance. The coast here was one continuous line, f undulating hills with precipitous cliffs, without a tree visible, but clothed everywhere in a vegetable carpet of beautiful and varied hues, while here and there tall rugged rocks rose sheer up from the glassy surface of the ocean, and in the dips of the coast a few cabins could be perceived, appearing like tiny white specks on the hillsides. The weather all day was fine and bright and the pure sea air peculiarly exhilarating.

I did not notice many birds, there being but a few gannets, or solan geese, shtarwaters and guillemots, with one or two of the small black petrels. In the afternoon, however, when we had fairly lost sight of land, a small bird flew over the vessel and seemed about to settle, but then darted away. It appeared to be some species of Anthus or pipit.

After leaving the Irish coast things changed for the worse, and for the next six or seven days we were

labour from $e$ a cork weath ciently enable

The were follow daily sistent with then d in ou floatin paddli and $o$ severa prize flew kind under a grey specie Th finer : maki We w and $t$ undes the a La there gulls first wher of $\mathrm{fu}$ prese fulm the 
ly out in deserted. of lights place to ch of an engines. y black-

I retire folling of $s$ against

aybreak, sea just he Irish h I was $s$; there $r$ of the r black-

$s$ of the til about view at itinuous ithout a egetable ere and e glassy st a few y white vas fine arating. t a few llemots, In the sight of seemed ared to

for the ve were labouring against terrible seas which washed the deck from end to end and tossed the great vessel about like a cork in their fury. However, after some days the weather, although still boisterous, quieted down sufficiently to allow me to remain on deck, and I was thus enabled to continue my observations.

The only birds which I observed in the mid-Atlantic were the fulmars, a considerable number of which were following the vessel, having been increasing in numbers daily since we left the Irish coast. They followed persistently in the wake of the vessel, wheeling and gliding with placid flight hour after hour, and every now and then dropping down upon the refuse which was floating in our track. They frequently settled on the water, floating buoyantly upon the waves, and now and then paddling vigorously towards some floating bit of offal, and on seizing it being pursued through the water by several other individuals who endeavoured to tear the prize from the fortunate possessor. They very often flew close alongside, but I never heard them utter any kind of note; most of them had the head, neck and under parts pure white, but in one or two they were of a greyish tint, there being light and dark phases of this species.

The day before reaching Newfoundland was much finer; the vessel moved steadily througl the water, making good headway, and the sun shone quite warmly. We were passing over the famous Newfoundland Banks, and the quantity of bird life was surprising, affording undeniable signs of the proximity of land and also of the abundance of congenial food.

Large numbers of kittiwakes were accompanying us ; there appeared to be quite 200 of these pretty little gulls-the majority being in immature dress-and they first made their appearance three or four days before, when I noticed four or five of them among the numbers of fulmars which then accompanied us; since then the present species had increased in numbers, while the fulmars had decreased, and I observed but one or two of the latter on this day. The flight of these little gulls is 
light and graceful in the extreme, they usually fly close to the water, upon which they frequently settle, but they often rise? 'rher in the air and wheel over the vessel, or several $a_{2}$ " ime come close alongside, flying close to the su . . o the water, their sharply curved wings movins ait! a quick regular beat; usually, however, they $: \mathfrak{l}$ : seen stretching in an irregular column far in the vessel's wake like white specks, alternately rising and falling, sweeping onward or settling in the lons line of foam which marks $h$." track.

I also observed here several small parties of the little auk or "dovekie"; these little birds fly heavily, close to the surface of the water, and in a compact body; they are easily recognised by their black and white plumage, and are usually seen swimming close together upon the surface of the water, but they dive instantly upon the slightest alarm, and remain below a considerable time, reappearing at some distance.

About noon a small bird flew on board in an exhauster condition and settled on the rail of the bridge, afterwards flying down to the deck, where it picked up a few crumbs, but on my approach it flew away again and was seen no more. I recognised it as a snow-bunting in summer dress, but the appearance of this little wanderer at such a distance from land was a matter of some surprise to mc. I noticed in addition one or two guillemots and petrels, and also several jaegers or skuas, including the long-tailed or Buffon's skua, the flight of which is swift and graceful. The porpoises, of which I observed small parties every day until now, had all disappeared.

The morning of Sunday, October I I, brolic in a day of singular fineness, and found us lying at rest in the land-locked harbour of the quaint little town of St. John's, Newfoundland. I lost no time in getiing on shore, and immediately started on a tour of investigation in the surrounding country. The day was cool and bright, but far warmer and drier than I had expected, and the sun sailed high in a cloudless blue sky.

Once clear of the little town I directed my steps

toward where cultiva ductior heaped bounda one up are eit sedime

The sparro chippir served migrat settling to feed flying sea I turbed approa utterin edge a cloudy moths the $\mathrm{spe}$ in the turbed having reddis

The away very e which Scotle appea and $p$ nant and $t$ this e of the 
fly close but they vessel, or close to d wings however, column ks, alterttling in

the little ly, close it body; d white together nstantly onsider.

hausted e, afterup a few ain and bunting tle wanof some o guilleskuas, fight of f which had all

a day in the of St. ing on igation ol and pected, steps towards the woods lying in its rear, and found everywhere much of interest. The land here is mostly under cultivation, but it is very poor, the most noticeable production being stones, which cover the fields and are heaped up on the roadsides, while all the walls and boundaries are made of slabs and pieces of stone piled one upon the other, and all the farmhouses and buildings are either made of wood or stone. The stone is mostly sedimentary deposits of various kinds.

There were very few birds about here, but I noticed a sparrow in a little plantation which may have been the chipping sparrow so well known in the States. I observed several small parties of the American robin or migratory thrush; they flew high a.. 1 were rather wary, settling in the thick fir plantations where they appeared to feed. I also noticed here a few American crows flying overhead. Walking back in the direction of the sea I came on a small lake by the side of which I disturbed a spotted sandpiper, which allowed a very near approach before taking to flight, when it darted off uttering a shrill peet, pcet, and settled again at the water's edge at some distance. The day had now turned out cloudy, but so mild was it that I caught several small moths here, including a "vapourer," exactly resembling the species $(O$. antiqua) which is to be seen so commonly in the streets of London. Up in the hills near by I disturbed a single fox sparrow, a large handsome species, having the lower part of the back and the tail of a reddish colour.

The next day I made my way on to the hills stretching away along the coast to the southward. There is a very extensive tract of rocky and mountainous land here, which presents much resemblance to the Highlands of Scotland, both as regards its flora and its picturesque appearance-hills and dales, covered with great boulders and protruding rocks, alternating with peaty bogs, stagnant swamps or clear quict mountain lakes, with here and there a rushing stream or miniature waterfall; and this extending as far as the eye can reach, the only sign of the proximity of man being yon hillside on which the 
pine stumps stand out grim and hoary, marking where the destroying axe has been at work. The forests of the island appear to be chiefly coniferous, and on the coast the rees do not attain to any considerable size, although there is a luxuriant undergrowth. In the great unexplored interior, however, are many tracts of forest and also some very extensive lakes.

A melancholy history attaches to the former natives of Newfoundland, for of the once numerous and powerful race of aborigines throughout the length and breadth of this great country, not one remiains. The colony of Indians on the west coast of the island belong to the Mic-Mac tribe, to whose persecution, added to that of the dreaded paleface, the extinction of the Beoths was due. Early in the present century proclamations protecting the Beoths, as these aborigines called themselves, were issued by the British Government, but as usual they came too late, for a very few years after saw the final extinction of these ill-fated people. Rumour, indeed, has it, that the last of the Beoths, a mere handful, passed across the Strait of Belle Isle in two canoes early in the present century, and landing on the opposite coast of Labrador, disappeared.

We left St. John's about noon on Tuesday, and during the remainder of the day were skirting the const of Newfoundland in a southerly direction. I observed a fair number of seabirds of different kinds, including a number of my recent acquaintances, the kittiwakes, and also several great skuas.

We passed the mouth of the Gulf of St. Lawrence cluring the night of October I4, and all the next morning were steaming down the coast of Nova Scotia, within twelve or fifteen miles of land, and with the surface of the water almost unruffled, so delightful was the day. The coast presents an almost uni roken line, dipping here and there into a valley where some little river enters the sea, and dotted at frequent intervals with tiny white houses, succeeded perhaps by scarcely distinguisnable fields or wooded and sterile hills, with here and there a church spire rising in the distance. On 
ng where forests of d on the able size, In the tracts of $r$ natives d power1 breadth colony of $g$ to the o that of Beoths amations $s$ called ernment, ery few ill-fated it of the of Belle ary, and ppeared. d during coast of served a uding a kes, and

awrence norning within rface of he day. dipping e river Is with ely dis. th here e. On

such a day one is tempted to forget that this is the "mournful and misty Atlantic," and that yonder coast is the home of those treacherous sea fogs, which are unfortunately far too frequent here.

Presently a dark line was distinguishable right ahead which soon resolved itself into a rocky point stretching out to the southward and known as Chebucto Head. The vessel's course had been altered, and we were now rapidly nearing the entrance to Halifax harbour. The sea here was unruffled and glittered like glass in the rays of the declining autumn sun, while the air was so remarkably clear and still as to produce a curious optical illusion, for the land appeared to be but a comparatively few yards from one, while it was in reality more than a mile away. Soon we were passing by the North-West Arm, winding serpent-like between its sloping and wooded shores, all gorgeous with the varied autumn foliage of the trees, and ere long we were lying alongside the wharf in the harbour of Halifax. 
CHAPTER II.

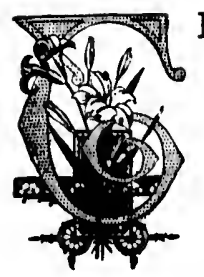

HE harbour of Halifax is said to be, perhaps, the safest and best in the world, and it certainly seems to deserve this eulogy, nature having rendered it impregnable to the elements, and man having done the same as regards his fellow-man. It is five or six miles in length, and is connected at the north end, by a narrow arm, with Bedford Basin, a great forest-lined sheet of water six miles long by four in width, and capable, according to the guide books, of containing all the navies of the world.

Halifax, the capital of Nova Scotia, differs not from the ordinary run of civilised cities, there being the usual proportion of substantially-built brick or stone houses sheltering the rich, and the usual proportion of wooden cabins sheltering the poor. It stretches for some three miles along the western slope of the harbour, and is terminated in the south by the entrance to the North-West Arm, which circles round for some three miles in the rear of the town. This picturesque inlet is about a quarter of a mile in breadth, with abruptly sloping sides, thickly wooded for the most part-cxcept on the town side, where some of the "well-to-do" have pitched their habitations, and converted its less abrupt shores into pastures and gardens. From the head of the Arm a low valley continues the circuit round to an angle at the south-west end of Bedford Basin, at a spot

kno situ

$\mathrm{N}$

the

a sh:

arou

occu

Den.

pictl

amo

are

unco

whic

teari

beds

avale

by a

way

curio

the $\mathrm{v}$

main

the $v$

with

hope

him

Or

stanc

form

awa

form

unde

boul

and

stan

croy

and

able

day

stuI

all 
known as Three-Mile House, from the fact of its being situated at a distance of three miles from Halifax.

Near the head of the Arm, and on the side away from the town, another pretty little inlet opens out of it, forming a shallow basin in the midst of wooded heights that tower around it; at the mouth of this inlet is a tiny island, occupied by the military, and known as Melville Island. Dense woods climb the steep sides of this extremely picturesque little basin, obtaining a precarious footing among the giant boulder s or fragments of granite which are piled in confusion everywhere, or with their roots uncovered by the fury of one of the numerous torrents which descend these rugged slopes after a rainstorm, tearing huge boulders and blocks of granite from their beds, and launching them with the momentum of an avalanche down their furrowed channels, accompanied by a shower of the débris which is for ever finding its way down to the already shallow basin below. It is curious to see these doomed trees, half uncovered by the violence of the flood, $y^{\prime}$ : clinging with all their remaining arms, or roots, to the torn and jagged sides of the watercourse, like a despairing swimmer, grasping with his ebbing strength some jutting rock in the vain hope of escape from the relentless torrent which bears him swiftly away.

On climbing to the ridge above, one finds oneself standing upon a more or less revealed plateau of granite, forming the crest of this mighty upheaval, and running away on either hand in ribs or buttresses, which form miniature valleys between, filled with a dense undergrowth springing up between the scattered granite boalders; or with solemn moss-draped firs, and pines, and hemlocks, staggering up the rocky slopes and standing out triumphantly here and there on the arid crown, alternating now and again with graceful maple and birch, while sometimes one looks down into a verit. able Valley of Death, the vegetation having had its brief day and moved on elsewhere, leaving gaunt, lifeless stumps, or prostrate and whitened stems and limbs, for all the world like a great littered mass of bleached 
bones. But up from this great charnel-house even now are springing new undergrowth and lusty youthful trees and herbage, and soon the roving birds will come here again, and the little red squirrel will make his nsst here once more when these firs shall have reared their proud heads over this iampart of granite to look or the decay of these stately neighbours of theirs.

Even on the crest of the hill old motherly Nature has covered up the grim mass of granite with a scanty film of débris, and watered it with tears of rain, and the forest has crept slowly up and across, and hidden the naked rock under its ample cloak, except here and there where a rugged patch stares barrenly out from the verdant fold of moss which borders it around and creeps slow? and steadily, year by year, up it from all sides, while the rock's furrowed back is for ever wearing and crumbling down to meet it. These are the haunts of my little favourite, the black snowbird, and whenever you approach softly up to ore of these little rock-patclies, you are almost sure to see this trim little bird hopping daintily, like our own familiar robin, over the harsh granite, now and then pecking in a half-hearted way at something, or perching motionless, with a seeming gentle contentment that sends an indescribable feeling through you when you involuntarily raise your eyes and glance around at the vast, silent forest-without a path, a habitation, and hardly a sign of animal life-which closes in around you.

All the way along from the heights above the NorthWest Arm, and above the valley previously mentioned, and above the great Bedford Basin, one vast continuation of granite ridges, and forest, and lake, and scrubcovered upland, runs back for miles upon miles, and here it is that most of my spare time during my stay at Halifax was spent, and most of the information given in the following pages was gathered. 

ke his n乞st eared their ook on the

Nature has canty film the forest the naked

\section{CHAPTER III.}

ere where e verdant eps slow!y des, while ring and haunts of whenever s-patches, 1 hopping he harsh d way at ng gentle $r$ through dd glance a, a habicloses in

e Northentioned, continuad scrubiles, and $y$ stay at given in

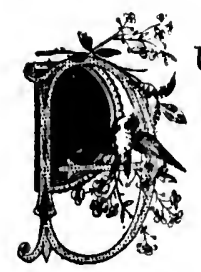

URING a short walk in the vicinity of Halifax, on the day after my arrival, I observed our European house-sparrow to be very common about the town; in fact it seemed even as impudent and abundant as in the streets of London, they having, no doubt, now been naturalized long enough to look upon these Anerican cities as their rightful inheritance.

I observed numbers of the American crow about the fields in the immediate neighbourhood of the town. This bird very much resembles the European species (C. corone), but, to my ear, its note is somewhat different, being sharper and more querulous, and at a little distance he ving a very great resemblance to the bark of a small dog. By the roadside, among the fields, I disturbed two or three American pipits, a bird which has much of the habits and appearance of our meadow pipit (A. pratcnsis) and, to an English observer, seeming to be almost the same bird. These individuals were evidently only visitors on their southward migration, their breeding range being to the northward, in Labrador and up to the Arctic regions.

On the morning of October i 8 , a fine, sunny day, I started out for a ramble in the direction of the North-West Arm, which I reached after a walk of nearly three miles. At this season the beautiful and varied hues of the autumnal foliage formed quite a 
striking spectacle as I approached the woods, and one which I do not think I have ever seen equalled by our English woods.

Passing the head of the Arm, I ascended the opposite hill by the St. Margaret's Bay road and soon came to Chocolate Lake, a small-sized lake, not more than a quarter of a mile in breadth, lying to the left of the road and shut in by private lands. The granite begins to appear at the surface just here, but I noticed that near the head of the Arm the surface is underlain by a large amount of dark-looking sedimentary rock, strongly impregnated with iron, and apparently formed as a deposit in some former estuary or mouth of a river. It is in a fragmentary condition and mixed with clayey loam, giving it a "pudding-like" appearance, and suggesting the action of some mountain torrent (or, perhaps, glacier) in the rounded form of the fragments. To. wards Halifax, however, almost the whole hill consists of this same kind of rock upheaved bodily.

On the outskirts of the forest I observed several juncos, or black snowbirds, hopping about the roads, but or my nearer approach they quickly vanisned into the under growth. This interesting little bird is almost silent except for an occasional slight chirp; its plumage is sober but pleasing, the bill being yellowish-white, entire upper plumage and the throat and breast dusky slate colour, and the abdomen and outer tail feathers white; in the female the upper plumage is greyishbrown instead of dusky slate.

Continuing along the road I came upon a series of beautifully clear and sparkling lakes, hemmed in by the picturesque forms of the granite hills, clothed with their rich autumnal garb of many-hued foliage of the scrub and underwond. These lakes drain from one to another for miles, Chocolate Lake being the termination of the series. The road here $r_{\text {mil }}$ for some distance alnig the water's side, while on the left rose precipitous wooded heights with occasionally a patch of low swampy ground intervening, covered with a dense growth of spongy moss and filled with swamp-loving bushes.

rema

semb

and I

near

milber

famil

count

anter

defing

reddi

remai

with

excep

men

garde

roads

Vanes

part

State to be

$\mathrm{Th}$

evide

a $\mathrm{sp}$

whic

from

I I

sides

The

ruby

brov

thic

was 
and one d by our opposite came to than a $t$ of the e begins sed that ain by a strongly as a der. It is ey loam, ygesting Jerhaps, s. Toconsists

several ads, but nto the almost lumage -white, dusky eathers reyish. ries of by the h their scrub nother of the ig the ooded round pongy
The day being particularly fine and warm many insects were abroad $i$, spite of the lateness of the season, which, however, hardly corresponds to the chilly and windy October of old England, for here the autumn is the most beautiful and enjoyable time of all the year, and is usially continued, in days of singular fineness, right up to the middle of December.

I found, however, but two species of butterflies still remaining. One of these (Colias philodice) much resembled the pale clouded yellow (C. hyale) of Europe, and I met with it in some abundance on the roadside near a strip of pasture land. The other species (Vanessa milberti) presented a good deal of resemblance to the familiar lesser tortoise-shell ( $V$. urtica) of the old country, but the markings on the basal half of both anterior and posterior wings constituted a clearlydefined patch of black, with only a faint indication of reddish markings on the anterior wings, while the remainder of each wing was unspotted reddish orange, with the edge of the wing similar to that of $V$. uvtica, except that there were no white markings. The specimen which I obtained flew from over the wall of a garden close by and glided along by a bank on the roadside, much as our English variety would do. Vanessa milberti appears to be spread over the larger part of North America, being found across the United States to the Rocky Mountains, but it does not appear to be very common in Nova Scotia.

This similarity to the old-world fauna is just as evident in the Heterocea or moths. There is, for instance, a species of Abraxas common enough about Halifax which can scarcely be distinguished by a casual observer from the "currant moth" (A. grossulaviata) of England.

I met with a small species of the Libellulidx in considerable abundance on the roadsides about the forest. The male insect had the abdomen above of a bright ruby colour, while the female had that part reddish brown, the abdomen being slightly depressed and thicker than in the $A$ grions of Europe, while the insect was also larger than the typical examples of that genus. 
Another much larger species of "dragonfly" (“devil's darning-needles" they are called here, as in some parts of England) was also not uncommon along the sides of the lakes. It has the characteristics of $\nexists$ shma and is nearly three inches in length and four inches across the extended wings, which latter are perfectly transparent; the slender cylindrical abdomen is blackish with several transverse markings of a pale blue, and with two stripes of yellow upon each side of the thorax. The flight of this insect is remarkably swift, and when struck at with the net and missed it darts off with such velocity that the eye can scarcely follow it. Sometimes it comes gliding down the rocky gore e or sweeping across the lake with a gentle movement of its wings, and then, suddenly darting upward, it snaps up a fly with an audible click of its jaws and glides on again in search of fresh prey.

Among the rocks and boulders on sunny slopes I found several marbled locusts (Locusta mamorata). When settled this insect presents a dusky appearance, the upper wings being mottled with dusky brown, but the lower wings are pale yellow, with a darkish outer margin, and are very noticeable in flight. When flying this insect produces a loud and peculiar "clicking" sound; it flies in an irregular manner and usually but a short distance, settling on the bare surface of one of the boulders, with which its mottled appearance when at rest somewhat harmonizes; if disturbed it leaps some distance like a grasshopper. The latter insects a!so abounded and I obtained specimens of two or three species.

In a little swamp I obtained a wasps' nest of a kind that is somewhat common in these parts. This specimen was at a height of about five feet above the swamp, and was fixed to a spray in the upper part of a bush, the twig passing through one side of the globe, and the small shoots and leaves being also carefully worked into the wall of the nest. It was about five inches in diameter and almost globular, the outer wall being composed of several distinct and separate layers or

envel

waspopeni in the have heigh one ten in

On the

Halif comp and $c$ of th Amer natur esped be it unriv prom raver WVes also exhil livin fema unlil galli amo facil $\mathrm{He}$ owls twe mar sma

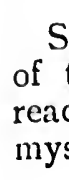


("devil's in some along the of Ashina ur inches perfectly s blackish blue, and le thorax. and when with such ometimes sweeping ts wings, up a fly again in

slopes I imorata). pearance, own, but ish outer en flying licking" ually but e of one pearance urbed it ie latter is of two

f a kind is speciswamp, a bush, and the worked nches in 11 being tyers or envelopes of a peculiarly thin, greyish-white kind of wasp-paper; in the lower part was a small circular opening through which the empty comb could be seen in the interior. Others of these nests that $I$ have seen have been in bushes and saplings, all at moderate heights, and in size usually not much exceeding the one above described, although I have seen one fully ten inches in diameter.

On October I9 I paid the first of many visits to the veteran naturalist, Andrew Downs, C.M.Z.S., of Halifax, who was then in his Sist year, although still comparatively well both in mind and body. His long and extensive experience and acquaintance with many of the older naturalists-dating back to Audubon in America, and Waterton, Gould, Jardine and other naturalists of the old school in England-imparted an especial interest to our conversation. To his credit be it said that his collection of birds stands almost unrivalled in point of workmanship and mounting. A prominent group, in a case of Corvida, was a pair of ravens with their nest and eggs, taken near the NorthWest Arm in the vicinity of Halifax, and in this case also are many medals and awards gained at former exhibitions on both sides of the water. Among other living birds were a fine pair of silver pheasants, the female of which is small and soberly clad and altogether unlike the beautiful male; also a purple or Martinique gallinule, which I observed could perch and climb among the slender twigs of a tree with considerable facility, and one of our old homely birds, the blackbird. He also showed me an exceptionally fine pair of snowy owls, the female of which I found measured fully twenty-seven inches in length, and was more heavily marked than the male, which was also appreciably smaller.

* * * * * * *

Since my return to England the news of the death of this simple-hearted and kindly old naturalist has reached me, and it is with sincere pleasure that $I$ find myself enabled to inscribe these few lines, in default 
of better tribute, to the memory of one who will live long in the minds of all those who knew him. He was essentially a working naturalist, and so leaves very little to retain him in the recollections of the younger generations; but his collection of birds, presented shortly before his death to Dalhousie College Museum, will perhaps form some slight memento of his work. 
will live

He was aves very e younger presented Museum, work.

\section{CHAPTER IV.}



HE 2 Ist day of October opened fairly fine, and the Fates seemed forbearing as I made my preparations for a long day in the forest. I was early astir, and the inhabitants seemed to be still deep in their slumbers as I wended my way past the few houses at the head of the North.

Wesi Arm.

With the exception of a few crows clamouring afar off as they straggled away in search of an early break. fast, the first living thing that met my gaze was a pretty little "chipping squirrel," "chipmunk," or ground squirrel as it is variously called. There he sat, on the bottom rail of the fence at the roadside, holding a nut or berry in his little fore-paws, with his fearless gaze turned round upon me as if to question the right of my intrusion-but without a trace of fear. All the stories and traditions of this little animal, treasured up for generations in the mighty country that overshadowed me even then, rushed through my mind as I beheld the little "clipmunk" for the first time in his native haunts. How different he and his surroundings were to the captives or the "specimens" I had hitherto only known! My eye wandering over the scene took in the fearless little creature sitting there before me on the rough-hewn rail, with the straggling bushes on either hand, while behind the grassy strip of meadow sloped down to the dark basin of Chocolate Lake, with the 
little ripples sparkling gaily in the morning sun, and all around towered the hanging woods of hemlock and pine. The moment I turned to continue on my way again he dropped off the rail and disappeared in an instant.

In the woods I noticed a good many chickadees, a most lively and scolding little black-and-white-headed species, with all the habits of the English titmice; it appears to me to be intermediate between the coal and marsh titmice of England. Sometimes associated with these were a few golden-crowned linglets (Regulus satrapa) which might readily be taken for the European goldcrest ( $R$. cristatus), so similar is it in appearance and habits. These little birds were creeping about in the firs and uttering from time to time their feeble note, just as their old world cousins do." Another representative of one of our familiar birds which I observed here, was the brown creeper, which is almost identical with the European species; it was creeping up the stem of a fir and uttering its shrill, slight note from time to time.

After passing over a zone of granite hilloclis, of such extraordinary irregularity that I had to leap and clamber from boulder to boulder to make any progress, I came upon a secluded little hog at the head of a small lake, which was shut in on all sides by rocky and wooded slopes, but connected at the farther end by a small rocky channel with another swampy forest lake. This bog had evidently formed a shallow part of the lake at no very distant period, but it was now almost dry, except at one part, where a small slnggish stream flowed into the lake, springing mysteriously from the howels of the eternal granite, not a hundred yards away, in the form of limpid crystal, but assuming an inliy appearance as it oozed slowly through the treacherous log. This stream necessitated very gingerly trealing on my part

* The most important difference between these two species nppears to me to be in the grealer size of the Amerienn bird, which is longer by half an inch than the European, while the bill is also somewhat stouter than is the laller. Like the Europenn species, the female $k$. satrapa has the crest bright yellow, instead of reddish-orange as in the male. 
$\mathrm{n}$, and all lock and my way ed in an

kadees, a te-headed tmice ; it coal and ated with (Regullus European ance and at in the ble note, er repreobserved identical

up the ote from

;, of such

clamber ;, I came lall lake, wooded

a small

e. This lake at ost dry, 1 flowed rowels of , in the earance This my part

es appears is longer unt stouter i. salrapa e male. in crossing it, as the apparent terra firma on either side was merely quaking peat-moss and swamp vegetation, and trembled beneath my foot, while the water oozed up as though it were a great sponge, and everywhere were little intersections and veins of dark-looking water. I espied a very handsome frog, having the under parts reddish, just here, but before I could catch it, it disappeared in the evil-looking water of the stream.

As I was leaving the bog, a marsh hawk came flying slowly over. Such places as these are the favourite haunts of this bird, as it can there find abundance of prey in the shape of lizards, mice, small birds, or the larger kinds of insects. This species is closely allied to the hen harrier (Circus cyancus) of the old world; its flight is slow and steady, and not very unlike that of its half-cousins, the owls.

There were abundant signs of the presence of "rabbits" (Lepus americanus) in all the more open spots here, yet I only saw one of these animals during the day, and that was extremely shy. In England this species is known as the "American hare," but through. out Canada and the United States it is almost invariably known as the "rabbit," and it is in fact not much larger than our rabbit, although possessing the habits and appearance of the hare; it also has the same leaping gait as the latter, the hind legs being particularly long.

From here I passed over the adjoining ridge, and after fording a little stream by means of the slippery, moss-grown boulders projecting from its bed, and forcing my way through the dense swamp buslues on the other side, I found myself on Long Lake, which is a lake of some considerable size and quite the largest one in this neighbourhood.

The spot I had reached was evidently one of the most secluded on the entire lake, solitary as it was, and having got to a drier and more open situation, I paused awhile to view the wild and lonely scenes which surrounded me. From here I could follow the winding of the lake for nearly a couple of miles ahead, where it became lost to view among the wooded hills. 
On my right, the arm I was upon was shut in by the granite ridge I had previously crossed, while to my left the shore was lower and clothed with dense woods which descended right to the water's edge, where the monarchs of the forest struggled with the dwarfish and mis-shapen underwood for a footing among the dripping boulders, draped with green moss and fern, and for ever kissed by the little ripples which sped across the crystal waters to cast themselves with a murmuring sigh against these adamantine breasts. The eternal lapping of the water as the ripples played among the boulders, was the only sound that broke the strange and almost weird stillness. Never a cry came from the vastness of the forest, never a bird cast a momentary shadow upon the lake-all Nature, in fact, seemed to be silent and inanimate.

A faint breeze was wafted over the lake, but not enough to sway the boughs of the stern and rigid pines and firs. The rippling waters sparkled brightly in the sunshine, but I looked in vain for aquatic birds upon their surface, neither was I able to meet with much in the dense and solitary woods through which I passed during my long tramp round the lake, but in a thick spruce-wood I flushed a single "spruce partridge" or Canada grouse-a rather handsome grouse which is said to be not very abundant anywhere in this neighbourhood at the present time.

The strangest fact about these forests is that, in spite of their lonely and retired nature, one is constantly imagining oneself in close proximity with frequented parts, or even habitations. Thus, whenever I emerged into a more open part, I fancied I detected signs of there being some track or clearing, although the idea was always dispelled on closer observation; or again I frequently inagined I caught glimpses of buildings through the trees, but if I endeavoured to find my way to them, they vanished as completely as the mocking mirage of the desert.

I was quite three hours on this lake, which at first appeared to be by no means so extensive, although 
by the to my woods ere the fish and lripping and for ross the muring eternal ong the strange he from a moin fact, but not d rigid brightly ic birds eet with 1 which ke, but lce par. grouse here in hat, in is con. ith frelenever etected though ration; sses of red to tely as it first hough continually opening up fresh arms and corners as I wandered on. I must have nearly made the circuit before I came upon a forest road to which I betook myself with some relief, and before long found myself on my homeward way. 
CTOBER 25.-To-day was Sunday, and relenting from his late fit of drowsiness the great sun-god shone forth in his splendour-flecking the ripples on the breeze-swept Bedford Basin with the golden light of daylureak and even bringing back a smile to the face of the dying summer.

Who could resist a stroll on such a morning as this, when even the bands of black-coated old crows indulged in hoarse laughs as they straggled over to the basin for a breakfast of fish or clams. Epicurean old rogues these crows are, enjoying the dainty "clam" as much as any unfeathered biped does.

As I approached by way of Three Mile House, a hawk sailing high overhead arrested my attention by the exten: and curvature of its wings, and also by its loud and peculiar cry, which may be syllabled as pectlechu, pectle-chu. It was a fish-hawk, or American osprey, a species which is very common in the United States, and also breeds sparingly on the coasts and lakes of Nova Scotia.

Up in the fir-woods I disturbed several American robins, an attractive bird and easily identified by its ruddy under parts; their note was a low inward chuck or chack. I also observed a raven (Covous corax principalis) near here flying over the road ; this form is almost identical with our European species, and is quite common in
Nova Scc America.

In pas: northern not unco some fer for the United in Nova

The 1 closely-: Americ: cipes fllir also ver

The small $r$ which and we teristic natura in the viously are po groun living habita obser

Dit

on $\mathrm{N}$ snow kingl and 1 head and parts the : 
Nova Scotia and also in other parts of Northern North America.

In passing I may mention that the great loon, or great northern diver, and also the red-throated diver breed not uncommonly on the Nova Scotian lakes, even within some few miles of Halifax. Both of these species are for the most part only summer visitors north of the United States, and I do not think they can be met with in Nova Scotia during the winter months.

The little pied-billed grebe, a bird belonging to a closely-allied group, is worthy of note as being the American representative of the familiar little grebe (Podicipes fluviatilis) of England. The American bird is just as widely distributed and abundant, while its habits are also very similar.

The great blue heron of North America bears no small resemblance to the common heron of Europe, to which it is in fact very closely related. It is a common and well-known species in the States, being as characteristic a bird there as our species is in England, although naturally not being met with in protected heronries as in the latter country. One morning, a few weeks previously, one of these herons-or "blue cranes," as they are popularly called-dropped down on a piece of marshy ground close to Halifax and not far from where I was living. But its temerity in venturing so near to the habitations of man cost it de rly, for it was soon observed and shot.

During a ramble in the woods around Melville Island on November I, I observed several juncos, or black snowbirds, and soms small parties of golden-crowned kinglets and chickadees. 'This last is a typical Parus, and has the crown, nape and throat black; sides of the head and neck white; mantle brownish-olive; wing and tail-feathers edged with white; and the under parts with a yellowish-buff tint, except the centre of the abdomen, which is white.

I also observed a single white-throated sparrow which crept away among the underwood uttering a slight chirp. This large and handsome sparrow has the head 
marked with a stripe of pure white in the centre of the crown, bordered on each side by a stripe of black, these again being succeeded by another line of pure white above the eye, with a yellow spot just in front of the latter; on the throat is a patch of silvery white from which the bird derives its name.

There were several crows about the woods, and I also came across a small party of American robins feeding on the ground in the woods. On being disturbed they flew up uttering a low chuck and settled on the bare limbs of the neighbouring trees, where they appeared to be reconnoitring; their call-note was a shrill whistle. The alarm note and the habit of flying up on to a bare branch reminded me very strongly of our redwing (Turdus iliacus), but systematists say that its nearest old world relative is the blackbird (T. mevillus), and they have accorcingly placed it in the sub-genus Merula, of which the latter species is the type.

The " migratory thrush," as it is also sometimes called, is a handsome species, and one of America's most typical birds. It leaves Nova Scotia about the end of October or the first week in November, moving south. ward to its winter quarters, and returning to the province again during the first week of April.

By the roadside I observed a fine specimen of the red admiral butterfly (Pyrameis atalanta); it settled upon stones with the wings expanded and was extremely swift in its flight. The American form of this insect is, I believe, regarded as racially distinct from the European, but the ordinary observer would certainly fail to detect any difference, either in appearance or habits. There is also a "white admiral" found somewhat commonly in Nova Scotia; it rather resembles the European variety, and I have seen it labelled as such in provincial collections, I believe, however, the species is designated Limenitis arthcmis.

I visited the same woods again on November I 2, and was fortunate in meeting with one or two Hudsonian chickadees in company with the golden-crowned kinglets. This chickadee is not nearly so common in the 
province as the black-capped species, from which it may be easily distinguished by its having the crown and nape warm brown instead of black, and the sides of the abdomen also warm brown, instead of pale buff, as in $P$. atricapillus. The name of this bird indicates its principal breeding range, and I do not know that it breeds in Nova Scotia, although it certainly does on Grand Manan Island, New Brunswick. 


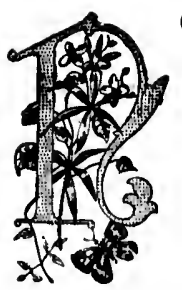

OVEMBER I4.-I visited, for the first time, the great woods rising from the western side of the Bedford Basin, and running back with but little interruption right into the heart of the province.

I left the Bedford road, which skirts the shore of the Basin, at a distance of some four miles from Halifax, and talking a narrow forest track, leaving the road at right angles, I ascended gradually until the great misty expanse of water lay far below me. Looking to the northward I could just discern the little town of Bedford, nestling in the valley where the river died away in the waters of the restless Basin; while out to the eastward I looked right cver the harbour to the dim stretch of placid ocean beyond, glittering like burnished gold beneath the rays of the afternoon sun, and with many ships dotting the hazy horizon in the far distance. But I moved on again and soon passed the brow of the hill, and the fair vision faded behind the sombre stretch of forest.

The greater part of the timber here consists of spruce and hemlock, although other descriptions are interspersed in many places. In some spots the trees rise tall and slender to a considerable height from a swampy bottom covered with a dense growth of moss without a blade of grass visible, while in all directions lie limbs or trunks of trees in every stage of decay-some of them,

although decayed plunges here; a croaks, overheac

A littl with sw have be them if able ex the tre shelving shallow very di nature bushes stream. from th

Beyc wood c togeth evenin brancl upon densit especi groun great never intens now which them dees, I can if $I$ splut place acqu 
although looking sound enough to the eye, being so decayed that in treading upon them one's foot frequently plunges into the heart. Very few birds were to be seen here; a crow at intervals sailed ovei, uttering hoarse croaks, and I also saw a red-shouldered hawk passing overhead with its somewhat irregular flight.

A little further on I came to a level botton crowded with swamp-bushes, so tangled and dense that it would have been hopeless to try to force a passage through then if one left the cleared track. From its considerable extent and flatness, as well as from the fact that the tree's ceased abruptly about midway down the shelving sides on either hand, I was convinced that a shallow winding lake had once existed here, and at no very distant time either, as was evinced by the spongy nature of the marsh or bog from which the mal-formed bushes sprang. Indeed through it still crept a sluggish stream, the waters of which were the colour of brandy from the masses of decaying leaves in its bed.

Beyond this again I came upon a high and dry sprucewood of astonishing density, the trees being crowded so together as to make it appear almost like the dusk of evening while I was in the wood. The sombre drooping branches of the spruce fir remind one of the plumes upon a hearse more than anything else, while their density almost effectually bars out the light of day, especially if the day should be a cloudy one. The ground beneath was covered with spruce-needles, with great boulders of granite protruding here and there and never a blade of grass visible. The stillness here was intense and almost oppressive, and was broken only now and again by the twittering of the small birds which occasionally came and settled in the trees, among them being a few black-capped and Hudsonian chicliadees, and some numbers of golden-crowned kinglets. But I came across no larger birds and not even any animals, if I except a single red squirrel, which coughed and spluttered angrily at me as I approached its lurkingplace in some low brushwood. Those who were not acquainted with this fearless little squirrel, would be 
very properly disconcerted on hearing the peculiar "whirring " or "rattle" emitted by it for the first time rwhile in these gloomy woods, for the sound commences in close proximity to one and with startling suddenness, giving rise, until the author of it is discovered, to unpleasant suggestions of "catamounts" and other undesirable acquaintances which one is still likely to meet with in this region. The "catamount," it should be remarked, is the name by which the American wild-cat is commonly known in the United States; it is not at all rare in the forests of Nova Scotia, and individuals are shot annually witilin ten miles of Halifax.

Leaving this somewhat gloomy region, I emerged into a tract which consisted of smaller and more varied growths of timber, and here I flushed a solitary ruffed grouse, a bird belonging to the genus Bonasa, "* and known almost invariably throughout North America as the "partridge."

I met an Indian towards Bedford, who told me that he had recently killed two moose in the woods beyond that place. The elk, or moose, + as it is called here, is still, happily, not uncommon throughout the greater part of Nova Scotia, but is never met with at the present time within twelve or fifteen miles of Halifax. In the more secluded forest fastnesses it still holds its own, in company with the "cariboo," more familiar to most people under its Old-World name of " reindeer."

This is particularly the case in the western portion of the province, amid the great wilderness of mountain, lake and forest, stretching from the South Mountains bordering on the Bay of Fundy away to, and beyond, Rosignol, the largest of the Nova Scotian lakes, secluded and solitary, with its winding expanse of limpid, sunbathed waters, out of which rise clusters of miniature islands sheer from its unruffled surface, upon which falls the dark shadows of the spruce and firs, which have

* B. umbellus togata is the designation of the form inhabiting Eastern Canada.

† Cervus alces. 
culiar $t$ time hences nness, to un. undemeet ald be ild-cat not at iduals

herged varied ruffed known as the

e that beyond lere, is er part resent In the own, most

ion of ntain, atains yond, luded sunature falls have

stood guard for ages over the unbroken solitude of these fairy islets. Now and again, through the forest, one catches a glimpse of the barren but inexpressibly grand masses of the eternal granite hills, with the army of grim old firs and pines halting stubbornly half way up their rugged sides; baffled for centuries, but still with that hoary tempest-braving line presented to the foe.

The moose and the cariboo have from time immemorial shared this undisturbed wilderness with their sometime enemy, the Mic-Mac, who still makes this spot the scene of his hunting operations. Here, too, the: bear, the beaver, the racoon and the porcupine are still found, while the American goshawk and the great white-headed eagle retreat into these fastnesses with the spoils of the chase, and here raise their broods secure from the gun of the farmer or the enterprise of the roaming eggcollector.

All along the coast stretching away to the southwestward of Halifax harbour, the great white-headed or "bald" eagle carries on his depredations. He is not quite such a "royal" bird as many writers have made him appear, unless incieed kingliness is not to be distinguishable from despotism. The white-headed eagle is at all times something of a despot. I think the favourite articles of his diet are fish and carrion, hence his partiality for the bays and estuaries of this wild and rocky coast. In connection with his liking for fish, Alexander WVilson's description of the bald eagle's spoliation of the osprey may occur to some. But he is also a great enemy to the poultry of the farmer, and has been often known to destroy young lambs, while he at all times commits great slaughter among the defenceless water-fowl, such as wild geese, ducks, the various species of gulls and other seabirds. 


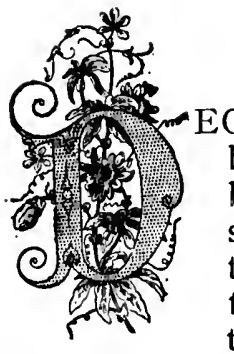

CEMBER 6.-I received three fine female birds of the American goshawk, which had been trapped at Beaver Bank, a place some distance north of Halifax, where they had been makin "reat havoc amongst the "rabbits." In fact, when skinning these individuals, I found that one had its crop crammed with the flesh of the animal mentioned, but the crops of the other two were nearly empty. These birds appear to pass southward about this time from their more northerly breeding limits, judging from the frequency with which they are to be met with in the province at this season.

This large and symmetrical hawk is one of the commonest of the larger birds of prey in Nova Scotia during the latter part of the year and again in the early spring, and it also breeds in many parts of the province, but I am not sure whether it is to be found there throughout the entire winter or not.

Years ago, within the memory of Mr. Downs, this fine species bred near Three Mile House, in the immediate vicinity of Halifax, but at the present day it is not found breeding within, perhaps, twelve or four. teen miles of the city. In the great undisturbed tracts of forest, however, particularly in the western portion of the province, it breeds somewhat commonly. I have examined several nests and eggs which were taken in

the regior and in ot hemlock it is a la $\&$ c., line two or frequent with yel inches $b$

Altho United limits of to its $n$ great de The adult, a by abo wings. This s] (A. pal deep $\mathrm{b}$ the na the bo dusky centra hand, with specie lower

I a be fa and I early

$$
\text { So }
$$
seasd the whit and body the 
the region of the Blue Mountains and Gasperaux Lake, and in other places. The nest is usually built in a giant hemlock about the latter part of April or early in May; it is a large structure, and composed of sticks, weeds, $\&$ c., lined with strips of bark and grass. The eggs are two or three in number, and in colour bluish-white, frequently unmarked, but sometimes faintly spotted with yellowish-brown. In size they measure about $2 \cdot 3$ inches by $\mathrm{I} \cdot 8$ inches.

Although not uncommon to the northward of the United States, this fine hawk seldom occurs within the limits of the latter, except as a winter visitor, and owing to its northerly range and inaccessible haunts, not a great deal is yet known concerning it.

The three birds previously mentioned were quite adult, and measured fully twenty-three inches in length by about three feet eight inches across the extended wings. The male bird, however, is considerably smaller. This species differs chiefly from the European goshawk (A. palumbarins) in having the upper part of the head deep black, with a partly-concealed patch of white on the nape, and the feathers of the entire lower parts of the body marked transversely with many fine zig-zag dusky lines, each feather also having a fine black central streak. The European goshawk, on the other hand, has the under parts thickly and distinctly barred with ash-brown. The immature bird in the American species, as in the European, has the plumage of the lower parts boldly marked in a longitudinal direction.

I also found the strikingly-marked harlequin duck to be fairly common in the province about the same date, and I saw many of these birds brought in during the early part of December.

Some black guillemots were also brought in. By this season of the year the deep black summer plumage of the adult had changed somewhat, the crown being white marked with black, the mantle barred with black and white, and the lower back and under parts of the body almost white. This species breeds commonly on the coasts of Nova Scotia and New Brunswick (notably 
on Grand Manan and other islands in the Bay of Fundy) and from thence northward to Greenland. It retires southward in winter, as far as Massachusetts, but appears to remain on some parts of the Nova Scotian coasts throughout the winter.

Up to December I5 the weather was generally fine and very mild indeed, except for sharp frosts at night during the previous week, but on the night of this day snow fell, and lay about two inches deep in the morning, although it disappeared during the day in consequence of the temperature changing and rain falling rather heavily.

On the 2Ist I noticed that the "rabbits" were nearly white; it is curious how quickly after the first fall of snow they seem to assume their winter dress.

Owls appear to be common in Nova Scotia about this time of the year. On this day I noticed about the town, and in the taxidermists' shops, both dead and living specimens of the great liorned, snowy, and barred owls, all which had been taken in the province. I also saw a fine stuffed specimen of the great grey, or cinereous wood orvl, a huge species, exceeding in size both the great horned and snowy owls, and even its near relative, the great Lapp owl of Northern Europe. In common with almost all Arctic birds, it is somewhat soberly attired, the plumage being mottled and barred with white, brown and grey. This individual had no doubt been taken within the limits of Nova Scotia, as the species even occurs within the bounclary of the United States during the winter. The summer home of this great owl is in Arctic America. Dr. Richardson met with it commonly on the borders of Great Bear Lake, and records that it keeps constantly in the woods, hunting hares and other smaller quadrupeds.

On the $27^{\text {th }} \mathrm{I}$ revisited the woods in the neighbourhood of Melville Island. There were not many birds about, but I observed some few brown creepers, which little bird remains in Nova Scotia throughout the year, as its Old World brother does in England,

although met wit northern British swell the

The $\mathrm{l}$ less con Halifax. what he Halifax eight ha miles of

The and en though ing in $f$ species. latter, : silky fe blue col are bar is enci whitish

Acco mimic, mimicr writers ventur are so other an op not yo But I Britis imitat specis birds. attrib of thi stree 
undy) retires , but cotian herally psts at ght of eep in e day d rain

nearly fall of

about about dead snowy, in the of the ;pecies, snowy pp owl ost all plumon and within occurs ag the is in monly that it lother

ibour-

birds which $t$ the gland,

although I have no doubt that part of the birds to be met with during the winter have migrated from more northern breeding haunts, as is also the case in the British Islands, where immigrants from the continent swell the number of our native birds in the winter.

The handsome and well-known blue jay seems to be less common than formerly in the neighbourhood of Halifax. Once or twice only have I heard the somewhat harsh squall of this bird in the woods around Halifax, although I have heard of as many as six or eight having been seen at one time within two or three miles of the city.

The blue jay is certainly one of the most beautiful and entertaining of the commoner American birds, although at the same time one of the most wary, possessing in fact many of the characteristics of our European species. The present bird is rather smaller than the latter, and has the head handsomely crested with loose silky feathers; the upper parts of the body of a fine blue colour, deepest on the wing and tail-feathers, which are barred with black and tipped with white; the neck is encircled with a black collar, and the throat is whitish, tinged with blue.

According to some writers the blue jay is an expert mimic, but for my own part I prefer to believe that the minicry exists more in the imagination of the said writers than in actual reality. Incleed, I would almost venture to say the same of all the other birds which are so commonly said to mimic the songs and notes of other birds and animals. I will not, however, express an opinion upon the mocking-bird's talents, as I have not yet heard the song of that bird in a state of nature. But I can distinctly assert that not a single one of our British birds is guilty -in its natural state-of consciously imitating any part of the note or song of another species. Perhaps the sedge-warbler, among our native birds, has most frequently had these powers of mimicry attributed to it, but, although as familiar with the song of this bird as with the chirpings of the sparrow in our streets, I can positively assert that I never yet heard it 
utter a note that had more than a slight resemblance to that of another songster, and I am therefore persistently incredulous with those who detect in its song the borrowed notes of other birds, inasmuch as I maintain that such resemblance is more accidental than real.

There is another species of jay found in Nova Scotia, but much less frequently than the last-mentioned. It is the Canada jay-also known as the "moose-bird," " whisky-John," \&c. This jay is a resident species, but is apparently not at all common in the greater part of the province, and certainly not so in the neighbourhood of Halifax. The bird is about the size of the blue jay, but of much more sober plumage, having the upper parts of a leaden-grey tint-with the exception of the crown, which is blackish-and the under parts dirty white, the tail being long, cuneate, and tipped with dull white. The whole plumage is long, soft, and loose, and no doubt forms an ample protection against the severity of the Canadian winter. 


\section{CHAPTER VIII}

ANUARY 2.-Overhead the dim blue of a cloudless sky, with pale stars fading from the dawn, and the great fiery sun peeping over the hills, while every tree and post upon the wayside loomed weirdly through the hurrying mist. Beneath iny foot the snow crunched sharply, every crystal sparkling with many colours in the first struggling rays of the rising sun.

Soon the mist rolled in great banks across the fields and filled alone the hollows, and out of these came an early crow or two, flapping leisurely along with an occasional querulous cry, and head turning from side to side continually on the look-out for plunder.

$\Lambda$ s I neared the North-West Arm, a solitary sleigh glided past me, the horse's trot falling softly upon the snow to the pleasing accompaniment of the tinkling bells. Crossing the head of the Arm, I turned to the south-east, ascending the road to the hanging forest of hemlocks above, standing out darkly through a faint enveloping mist, tinted with a soft light by the morning sun.

Presently I left the road and plunged into the solitude of the fragrant pines and hemlocks, stepping over the virgin snow that lay, crisp and glistening, fully five inches in depth upon the ground. There were a few wary old crows about these partially cleared outskirts of the forest, calling to one another from the tree-tops 
with a loud imperious note, much like that of their Old World cousins. They appeared to be at least as wary as the latter, and it is difficult to shoot one of them, while residents in this part will seriously assure you that it brings "bad luck" to kill one of th ese birds.

Among the pines here, I met with a pair of redbreasted nuthatches, a bird which has much of the habits and appearance of our familiar species. I noticed that these birds crept about upon the lesser limbs of the pines, usually the higher ones, and I did not hear them utter any kind of note. Like other small birds at this season, they traversed the woods from one tree to another, with but little stay upon each, and I soon lost sight of them. Now and again I observed a few crossbills or grosbeaks (I could not be certain which) at work upon the cones in the summits of the taller trees. I also heard the sibilous note of the brown creeper, and detected a pair of these little birds creeping up the trunk of a small fir.

In spite of the cold I noticed some few of the small red squirrels about soon after entering the forest. Unless alarmed they were quite fearless, and would call one another from the branches close to me with a curious little cough or bark, also squeaking and chattering :-

"Sprang the squirrel, $\Lambda$ djiclaumo, In and out among the branches, Coughed and chattercd from the oak tree."

On the whole, however, very little life was to be observed about the woods during this long ramble, sometimes through great tracts of forest with nothing but the crunching of the snow under foot to break the strange stillness, or across densely-woorled bottoms strewn with great granite boulders now covered with four or five inches of snow, but beneath this green with the luxuriant growth of moss, while after a time I gained the higher land, open and scrub-covered for the most part, but with many little hollows filled with a dense growth of young hemlocks and firs dim with the faint mist of a January day, clothed with long tufts of 
their ast as ne of assure birds. f redof the es. I lesser 1 I did other woods upon again ld not sums note these

small forest. lil call vith a hatter-

to be imble, thing k the ttoms with with me I $r$ the ith a the its of

tree moss and decked with white and green lichens, recalling forcibly to the mind Longfellow's beautiful lines :-

"The murmuring pines and the hemlocks, Bearded with moss and in garments green, indistinct in the twilight, Stand like Druids of old, with voices sad and prophetic, Stand like harpers hoar, with beards that rest on their bosoms."

To me there is nothing wearisome in these woods. I am, indeed, far more lonely and depressed among the habitations of man and the bustle of his selfish avocations than in the most secluded forest, for in these great wilds the spirit of Thoreau and of many another brother in Nature, rises up to bear one company, filling the mind with an absorption and obliviousness to care that I have tried in vain to attain to within the sordid limits of my chamber. And then the birds and beasts that one follows on unweariedly into their most sacred retreats, as they move restlessly through the forest, intent upon their own pursuits and careless of your stealthy approach and engrossed, untiring observation ; squirrel and crow, nuthatch and tree creeper, all alike oblivious of your silent intrusion and even your very existence, while they gambol, and court, and feed, each in its unconcerned way, until the tyrant-biped or quadruped -puts an end to their harnony, and often also their existence.

How puerile and foolish it seems to presuppose that aught of real beauty or peace exists beneath the pleasant sunshine, the sombre undulating forest, and the virginwhite robe that Nature wears to-day! Always amid this semblance of peace and gentleness, and these timid birds and animals, or the insects of the past summer, lurk the ever-recurring agony and the violent death. How vain, indeed, it is to think of peace, in a system whose harmony and balance rest solely upon Utilitythe Survival of the Fittest! 


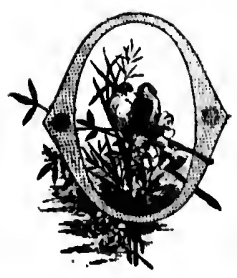

$\mathrm{N}$ January I7 I visited again the woods around "Melville Island, hut saw very few birds beyond several "partridges" and chickadees-or black-capped titmice-and also the ever-present crow.

On the 24th I observed snow-buntings for the first time near Halifax. No doubt the recent great snowfall and severe cold had driven them southward, as they usually make their appearance in these latitudes after the first severe snowstorm. Nothing can exceed in interest the sight of a straggling party of "snowflakes" drifting across the snow-covered fields, or sometimes flying close over the road with their wavering flight and feeble twittering notes.

I observed some small parties of golden-crowned kinglets in the woods again on January 30 , and since I had failed to detect any of these birds during the previous six or seven weeks, I had good reason to conclude that they had moved further to the southward during that period, to escape the severe weather.

Up to February I6 small flocks of snow-buntings were still about the fields in the vicinity of the town, picking up a precarious livelihood from the dung-heaps and refuse of all kinds, also paying great attention to the seeds contained in the crowns of the few withered plants which projected above the uniform stretch of snow in the fields and along the ditches.

$\mathrm{Th}$ of a stran these the trave clim retur the they adva

and som the nor mo the wh all wh sor the lea wh wc for bi in 
The sight of these little fugitives from the rigours of a Polar winter provides mental pabulum for many strange reflections, and so one finds oneself thinking $w / h y$ these small frail creatures-to whom most would deny the possession of reason-why and how they should travel southward so unerringly to these less ice-bound climes; and why-still less explicable-they should return as unerringly to those same Polar regions when the fitful Arctic summer sets in-nay, even before, for they depart from their temporary refuge long before the advance of genial spring.

Years ago such questions as these were left unargued, and were, indeed, unanswerable, but now we have learnt somewhat of Nature's secrets, and can reason back to the time when a warmer climate reigned over the far north, and the birds were stationary, as are those of more temperate latitudes at the present day. Then, as the great winter, or ice age, set in, one can picture the whole animal life of this great area being forced gradually southward with the extension of the cold region, while in the brief spaces of the Arctic summer this southward movement would naturally cease for a time ; the frost-bound trees would perhaps struggle forth into leaf acrain; the dormant insects would again appear; while the birds, by reason of their powers of flight, would even venture to return somewhat towards their former breedine haunts. This may be only hypothesis, but it seems to clear away much of the shadow of the inexplicable surrounding the question of migration.

A few northern shrikes or "butcher-birds" came under my notice during the month of February, and one day a bird of this species was actually to be seen in one of the principal streets of Halifax, to the no small terror of the over-confident alien sparrows, one at least of which it pursued and captured. This bird is closely allied to the grey shrikes of Europe, and possesses similar habits, including that of impaling its prey upon thorns.

There were also in the vicinity of the town at this season a somewhat unusual number of "saw-whet "or 
Acadian owls. This owl, the smallest in Eastern North America, is quite a common species in the province of Nova Scotia, particularly at the present season.

By the 28th the snow-buntings had all disappeared, the weather being milder, and on this day I observed the black snowbird again in the woods by the North-West Arm. I also noticed a flock of shore larks - "horned" larks in New-World phraseology-circling over the fields; they flew in a very compact troop, and appeared to number quite one hundred. Crows, I noticed, were already in pairs, although not nesting here until the latter part of April.

March I 3 brought very little change in the weather, the snow still lying ten or twelve inches deep in the woods, while the only birds I took notice of during a brief ramble were a few chickadees, one of which I disturbed as it was busily engaged at a bunch of pine-cones which had lodged in a bush. I observed, however, that the squirrels had already commenced to prepare their spring nests in the fir-trees.

On the $26 \mathrm{th}$, also, the weather was unalteredalthough not particularly cold-the snow still lying undiminished in the woods. 


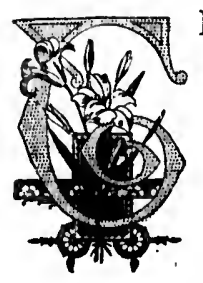

HE first of April opened the month well, but the succeeding day was even finer and warmer, and in consequence the snow had already quite vanished in the fields, and was rapidly diminishing in the more open parts of the woods. Indeed, in sunny little glades, where the snow had all melted, I several times startled hybernated individuals of the Camberwell beauty butterfly (Vanessa antiopa), an insect which is very commonly distributed in Nova Scotia. They almost invariably settled upon the ground, with wings outspread to catch the full warmth of the sun's rays, starting up suddenly upon one's approach and flying off with extreme swiftness.

I disturbed several chickadees from an old decayed stump of a tree, about ten or twelve feet in height, in which I found they had commenced several holes, probably with the intention of forming nesting cavities. Some numbers of crows are always to be found in the morning in the woods upon the North-West Arm, along the shore of which the ground beneath most of the trees is strewn with clam-shells, proving the extent to which this favourite bivalve enters into the "bill of fare" of these omnivorous birds.

In several parts of the forest I found a few fox sparrows -a large and handsome sparrow, the largest in North America, and noticeable from its ruddy tail-coverts and tail, and the bold blotches or markings upon its breast 
and flanks. I met with the first party of four or five of these interesting birds among the rocky woods near Melville Island, and followed them back into the woods for some distance, while during the remainder of my ramble I several times came upon a few of these birdsalways in the most secluded and dense woods of fir and hemlock, and generally in a spot where rocks or boulders appeared. Although of such shy and retiring habits, they seemed rather unsuspicious, and allowed a somewhat near approach unless alarmed. I often saw one upon the moss-covered boulders, apparently seeking for insects or their pupx, while I sometimes approached quite close to them when perched in the trees, and I noticed that they always settled low down on a dead branch or bough, against the trunk, where they sat so motionless that they might be easily passed unnoticed. The only note I heard these birds utter, and one which seemed common to both sexes, was a low and somewhat plaintive whistle.

In the fields nearer the town I several times noticed the familiar chipping sparrow. This sober little bird usually sang from the topmost spray of a bush, the song being a weak, but not unpleasing, little trill.

The following day (April 3) was cloudy ir the morning, but cleared up before noon, and was very fine and warm the rest of the day. I walked over to the Bedford Basin in the morning, and frem thence round to the North-West Arm, the walk being thoroughly enjoyable, although not much of interest was to be observed on the way. In the woods by Melville Island I came across some newly arrived " robins" or migratrry thrushes, and also observed a pair of the prettilymarked pine-creeping warblers upon the trunk of a huge pine, while in the trees and bushes close by were a few "yellow-rumped" or myrtle warblers, this species being about the earliest to arrive of the many warblers which visit the province. They mostly frequented the bushes or small trees, and often uttered a simple, pleasing warble.

I heard a chickadee here uttering a note or song 
or five ods near e woods $r$ of $\mathrm{my}$ birdsfir and boulders habits, a somesaw one king for roached $s$, and I a dead hey sat sed un. ter, and is a low

noticed tle bird ash, the e morn. ory fine r to the e round roughly s to be Island nigra. orettily. $k$ of $a$ y were species arblers ed the iimple, almost identical with that of our great titmouse; it consisted of the three notes only, however, there being no quick repetition of them as in our bird.

Just before dusk I noticed fourteen geese-probably Canada geese-flying over the town from west to east at a considerable height, and apparently following the coast line. My attention was drawn to them by their occasionaliy-uttered cry, a deep honk, honk, and they were then flying in straight single file of twelve, with two on one side abreast, but soon afterwards they opened out at this side into an irregular $\mathrm{V}$-shape.

It was on this night, also, that I witnessed a beautiful aurora to the northward. It lasted several hours, during which period the faint shifting rays of light illumined the whole sky to the north and north-east, producing at one time a most striking and beautiful effect.

The morning of the I 5 th opened very dull and cloudy, and there was not a breath of wind to be felt, while there seemed to be a promise of snow later in the day. I left home soon after daybreak, and after two or three miles' walk struck the woods near Three Mile House, on the Bedford Basin, from whence I passed through continuous dense woods in a north-westerly direction all the morning.

Soon after entering the woods I came upon a party of golden-crowned kinglets in a dense undergrowth of young firs, and except for these there was hardly a bird to be found in this part of the forest. Some of the firs here were of a prodigious size, and near the summit of one I noticed what appeared to be an unfinished nest of a hawk or crow.

A little farther on I came to a small sluggish stream flowing through a swampy hollow. The brandycolcured water was fringed upon either side $\mathrm{with}^{+\mathbf{h}_{2}}$ curiously-contorted swamp bushes, while here and there a fallen trunk bridged the strean1; but I had learnt by experience not to trust these seeming bridges, for although looking sound enough to the eye, they are usually mere shells from which the heart has long since 
rotted away. I noticed, as an odd circumstance, that for some distance this little stream formed an abrupt boundary between two totally different descriptions of woodland, for while upon one side the woods consisted of (at this season) bare and leafless birch and similar trees, on the other side of the stream rose dense and funeral-looking spruce woods. I heard a woodpecker tapping here, and followed it a short distance, but could not obtain a view of it. I also noticed a white-breasted nuthatch among the firs, as well as several chickadees and brown creepers.

Leaving the stream I then struck through the forest until I came upon a long ravine in the dense woods, with sloping sides and an almost level bottom, which was sparingly timbered, and with a sluggish stream winding along it, and on which the snow still lay thickly, as it also did in many spots in the surrounding woods. I saw here a large nest of the American crow, fully sixty feet up in the fork of a large and almost limbless maple, but I did not attempt to ascend to it. Crossing the ravine I pushed on again through very thick woods, varied occasionally by higher and more open rocky ground covered mostly with scrubby brushwood, but saw nothing more, and so retraced my steps and struck a track leading back to the Bedford Basin. Just here the trees were chiefly hemlocks, and veritable giants of the forest they were, many of them being fully four fret in diameter near the ground and towering to an immense height.

While passing down this track the snow commenced to fall gently, adding to the lonely and desolate nature of the forest. I noticed many old burrows of the woodpecker in the summits of the bare and whitening trunks that met the eye on every side, but saw very few birds of any kind until I came to a low swampy fir wood, in the midst of which was a shallow pond where the frogs were croaking dismally. Here a large barred owl flew close past me with its peculiarly light and noiseless flight, and settled upon a dead tree a short distance behind. The habit of flying in the 
ance, that an abrupt iptions of consisted d similar ense and odpecker but could -breasted hickadees

he forest e woods, n, which stream thickly, woods. piv, fully limbless Crossing $k$ woods, n rocky ood, but d struck ust here riants of four fret mmense

\section{menced}

nature of the iitening w very wampy pond a large y light tree a in the daytime in this species is well known; it was shortly after noon when I saw the present individual, and snow was falling rather fast at the time. I judged it to be a male, the female being considerably larger in size, and in fact almost rivalling the great horned, or American e le-owl.

Continuin: on my way I disturbed a pine grosbeak from the ground at the foot of a fir-tree; this is a very handsome scarlet-tinted bird and is by no means unknown in the province at certain seasons, although breeding farther north. Pushing on again, the great foggy expanse of Bedford Basin soon came into view below me, and before long I reached the road which winds round by the water's edge, and started homeward, well satisfied with my day's ramble.

On the following day I came across a solitary pair of fox sparrows in a rocky and elevated spot by Melville Island. These were evidently very late stragglers, as the majority must have departed to the northward ten day's before, this sparrow breeding farther north, in Newfoundland and Labrador.

At about II a.m. on the 25th I was in the roods near Three Mile House when my attention was attracted by a great outcry among a party of perhaps a hundred crows wheeling over the tree-tops at a short distance. I soon perceived that they were vigorously mobbing a large barred owl which was sailing leisurely along in the direction of the Bedford Basin, the crows closely surrounding the stranger, and darting down so close as almost to touch it, uttering all the while loud and incessant outcries. The owl seemed but little concerned by their attacks, however, only occasionally uttering a low harsh scream or growl, while it sailed on straight ahead, soon leaving the majority of its persecutors behind and being only pursued by four or five of the crows, which followed it right over to the great woods across the Basin. No doubt the excited resentment of the stranger's visit by the crows was largely due to the fact that the latter were actively engaged in nesting operations. 
It was late in the afternoon as I returned homeward through the woods near the lake at Three Mile House, and quite a number of robins were singing in the tree-tops at the outskirts of the woods. Their song is loud and possessed of little variation, but still attractive; it is certainly inferior in mellowness and compass of voice to that of the vocalist's Old World cousin, the blackbird. The song may be readily syllabled as gie-it$u p$, gie-it-up, gie-it-up, pilly, pilly, but it is strange what an amount of rivalry and assertion it conveys, for 'ie birds will sing one against the other with a surprising vehemence and vigour for an hour at a time.

In a shallow grass-grown pond which I passed before leaving the woods the frogs were holding a merry concert. Heard in the twilight, in the stillness of the forest, there is something plaintive in their clear and shrill peet, pect, uttered at first by one only and being every time answered by another and another, until all join in one swelling chor!!s-

"A.d anor : thousand whistles Arswe:ed over all the fen-land." 
ed home. iree Mile singing in heir song till attrac1 compass ousin, the 1 as gie-itnge what $\mathrm{s}$, for 'ie urprising

\section{CHAPTER XI.}

ed before erry conhe forest, hd shrill ng every 11 join in

AR different to all our old-time conceptions is the dawn of a New World May-day in the solitudes of the primeval forest! No groups of villagers, no merry dances, no gaily-decked teams of horses-nothing but the grey silence of day-break, and the allextending forest.

As I stand, the woods close in around with their array of shadowy forms looming through the uncertain light of dawn. A space further on a low boulder forms a ready couch. Here the ghostly army of the forest fades away, for below is the sea, now lying placid and dumb, with a faint slow heave of its fair bosom, and a mute, passionless appeal which draws one's thoughts out to it and steals them a way seaward - over to that Old World from which the face was so resolutely turned.

These are the moments of reverie, undisturbed by any sound save the ripple of the tiny waterfall near at hand. Here it is always water-little streamlets splashing from every hillside and chasing one another down among the hollows and shallows and the littered granite; down, down, and away headlong to the sea-

"Run home, little streams,

With your lapfuls of stars and dreams "-

singing, as they run, little intermittent snatches of strange music; now like the faint, far tinkling of silver bells, and again like the sedge-bird babbling by 
the brook in ifar-away England. But it is not peace they sing of, not simple contentedness, for into these reveries comes a great, passionless unrest, born of thoughts of a breadth and scope far too subtle for the mind to grasp, as sweeping and as unabiding as the ocean that frets away for ever upon the granite below, and as untrammelled by the narrow injustices and heart-searings of the passionate world of man.

But a faint rare flush upsprings in the pale east, deepening to a glow, ascending to the zenith, and overspreading until but a lone pale star twinkles low in the west-a jewel glistening upon the train of flitting Night, until up from across the sea peeps a great fiery disc of dazzling gold, flashing forth the triumph of spring over earth and sea and sky, and waking to busy life the countless denizens of field and forest.

Already the feathered choir have been heralding the coming of the great Life-giver, and the woods are astir with song-the petulant whistling of the "robin," the chant of the water-thrush, and the many trillings of the warblers, while along the shore the sable crow swells the symphony with discordant music. But anon comes another and a stranger song from the shady recesses of the underwood-notes sweet-toned and changing, like the babbling of a brook over stones, and with as sad and stately an undercurrent. It is the song of the hermit thrush-bird of the dark and gloomy forest, the secluded swampy hollow, girt round with dense underwood and crowded with tall breathless firs, staring up for ever from out of an endless twilight-

"From deep secluded recesses,

From the fragrant cedars and the ghostly pines so still, Came the carol of the bircl."

$$
x \text { * * * * * }
$$

The first of May seems to commence the spring in Nova Scotia, judging by those sure guides, the birds: and indeed the day was so delightfully fine that I felt justified in honouring it as the first day of spring. The trees, however, had scarcely commenced budding as yet, although the snow had all vanished in the woods. 
Down by Melville Island I came across five or six nearly completed nests of the American robin-none of them, however, containing any eggs. Orie was placed at the extremity of a branch high up in a pine, about thirty feet from the ground, this being the greatest altitude at which I ever saw the nest of this species. Another was straddled on the thick horizontal bough of a hemlock, at a height of not more than eight feet. A third was cradled in the drooping branch of a hemlock, and so low down that I could touch it with my hand; while one was even placed in the fork of a bare silver birch. Both in situation and appearance the nests closely resembled a neat example of the European mistle thrush's nest.

The robin, or migratory thrush, is the first to commence breeding among the smaller species of birds found in the province, and as the period when it commences nest-building corresponds exactly with that of the Old World blackbird and mistle thrush, it may be readily imagined how much later the spring commences in Nova Scotia, in spite of the fact that it is several degrees farther to the southward than England.

In the same woods I disturbed a downy woodpeclier from a decayed fir some eight or ten inches in diameter. It allowed a very near approach before revealing itself, when it darted on to another stem a couple of yards away and clung motionless to the bark, peering down at me for a moment or two, and then flew silently away. I found that two excavations had been commenced in the tree the bird was disturbed from, both of them being about twelve or fifteen feet from the ground, and being scarcely larger than those made by our lesser spotted woodpecker, but they did not penetrate more than a couple of inches.

The downy woodpecker-sometimes inappropriately called the lesser "sap-sucker"-is a very small species, in fact, the smallest in North America, being not more than six inches in tota: length. It is noticeable from its black upper plumage and white lower parts, contrasting with its scarlet hind-head and crest. This 
little woodpecker has a curious habit of d*mming continuously upon a resonant part of a decayyd limb, probably with the object of calling the attention of its mate, for when it ceases for a while an answering tapping may be plainly heard proceeding from another direction.

On the morning of May 7 I observed the first swallow in the neighbourhood of Halifax; it was of the species known as the white-bellied or tree-swallow, and distinguished by the entirely white lower pauts.

During a ramble in the woods by the Bedford Basin I was much amused, while taking a brief rest upon a fallen tree, by the actions of one of the little red squirrels, which scampered along the ground around me, and sometimes came close up under the cover of the brushwood, uttering its shrill and fairly startling rattle, and coughing, spluttering and whining in a most ludicrous manner, as if in a great rage at my intrusion upon its retreat.

The troublesome "black fly" (Simulium molestxm) a dipterous insect allied to the gnats, makes its appearance in unpleasant abundance at this season. It appears, however, to be entirely confined to the more secluded and damper parts of the woods.

In a rather open part of the forest I came upon a nest of the "flying squirrel" (Pteromys volucella) in a young pine at a height of about twelve feet. Both the squirrels were at home, for on tapping the nest they left it and made their way silently up to the r.-anches above, where they remained clinging mute and motionless to the limb in such a manner as to almost escape notice, owing to their resemblance to a patch of fungi, or other foreign matter. Their habit, indeed, is to remain at rest during the day, and to come forth only after sunset, when they may sometimes be seen gliding swiftly through the air from one tree to another. They are very pretty little animals, about the size of the common red squirral, and of a light brownish, or rather drab colour above and silvery white below, the fur being soft and silky and very close. The animal is furnished with an extensible fold of skin on either side, from limb 
to limb, which is stretched tight when the limbs are extended in leaping through the air; the extension is aided by one of the toes of the 're-paw being much lengthened and inclined backward; the tail also is broad and concave below.

The trailing arbutus, the exquisite little "mayflower" -emblem of Acadie-is in full flower about this time of the year, and sure enough during the day I found it growing in great profusion along the side of a forest track. The pretty little white flowers, half hidcien among the leaves, remind one somewhat of our white violet, and it would be hard to decide which possesses the sweetest scunt. All the esteem in which the violet is held by Old-world Nature-ivvers is lavished upon the little "mayflower" here-and in much the same way, for each spring it is sought for diligently, torn from its enfolding leaves and carried heartlessly away to droop and die in a glass or vase in some forgotten corner.

But as with flowers so it is with birds. These beautiful denizens of field and forest have no encmy more to fear than civilized man, who is ever on the watch to slaughter -ever inventing fiendish appliances to capture and cage them. Better, a hundred times better, were these celestial pipers stretched stiff in death by some more natural foe than doomed to pass their innocent lives cooped up in small wired prisons far away from the haunts of their delight, to sing their plaintive strains day by day into the deaf ears of a heedless and uncaring crowd. Strains of sorrow and upbraiding are they as summer fades and the little prisoner longs for the clear sweet air and his kindred's society among the quiet upland stubbles. Dreary songless days of winter, amid slush and fog, and far from his native woods and meadows, now covered deep with crisp sparkling snow, every little coppice glistening with the fairy forms of a thousand enchanted palaces rising turret upon turret and spire upon spire, desolate and silent in the stillness of morning; until perchance the sable blackbird breaks the spell as he darts out noisily, scattering a million sparkling gems in his flight, and chasing away the fairy 
vision with his hearty laughter. So spring comes, and from his narrow cage the poor imprisoned songster pours forth incessantly his tale of love to far-away ears that hear not, straining his soft breast against the cruel bars that alone separate him from life and liberty. And so the spring passes, with its gladness of warmth and sunshine, its busy birds, and insects, and flowers, while the little captive ceases his song, and, perchance, languishes gradually away, and before spring returns Death has ransomed him from his troubles-his allpowerful touch has burst the narrow prison and carried away the frail remains to winnow in his mighty granary and plant again in the garden of Life, who will water them with living tears until the eternal spring shall raise them once more into some fair blosson? that will go forth afresh to scatter seeds of truth and veauty upon the earth. 
es, and ongster ay cars e cruel liberty. warmth lowers, chance, returns his allcarried

\section{CHAPTER XII.}

granary

1 water all raise will go ty upon

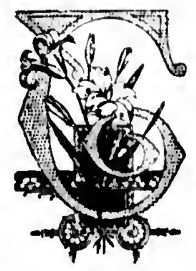

HE next day found me again in the woods by Melville island, and on inspecting the robins' nests I discovered that the birds had commenced to lay, there being three eggs in two of the nests, two in another, and one having four. This last nest was the neatest of them all, its situation being the drooping branch of a small hemlock. It was not so bulky as the nest of our mistle thrush, but similar in construction, the exterior being constructed of small twigs and tassels of green tree-moss (Usnea), while the lining was a neat cup of fine dry grasses; I noticed also that the nest was secured to the branches with a small quantity of moist loam, while there was the usual intermediate wall of the same in the nest itself. The eggs of the "robin" are unspotted, of a uniform and rather deep greenish-blue, measuring about $I$ ' Io by $\cdot 85$ inches.

By May 13 the ruby-throated humming-bird had already accomplished its wonderful journey to the province, as I was shown one which had been sent from Kentville on this date. I was informed that the previous spring one of these beautiful little creatures visited the flower-box in one of the windows of the house I was stopping at and was observed hovering there for some minutes.

Fine weather on the I th again took me to my old haunts on the Melville Island inlet, and in the woods 
here I noticed some more nests of the "robin," but very few other birds seemed to be interested in nidification as yet. In a little open spot I came to a decayed maple stump, about twelve feet high, near the top of which a pair of "flickers," or golden-winged woodpeckers, had been very busy excavating a suitable burrow for nesting purposes. The cavity within was large and roomy, being about ten or twelve inches deep, although apparently not yet completed, while the whole ground for yards around was littered with the chips and dust in evidence of the arduous undertaking.

This habit of building has earned for the bird the rather curious appellation of " high-hole" in some parts of the United States. It is under this name that Whitman, a true naturalist (as every real poet needs must be), mentions it :-

"Put in April and May, the hylas croaking in the ponds, Bees, butterflies, the sparrow with its simple notes,

Blue-bird and darting swallow, nor forget the high-hole flash ing his golden wings."

Near here I visited a nest of the flying-squirrel, which I discovered a few days before in a hollow in a small stuinp and only four or five feet from the ground; there were then three young squirrels, blind and naked, and the female in the nest, but I found on re-visiting it that the squirrel had removed her young from the nest, no doubt to a safer hiding-place.

Passing from here by a slight track through some rather open rocky ground, I startled a nighthawk from the ground close to the path. Like its English cousin, the nightjar, the bird harmonises well with its surroundings, and also crouches so still that it is never seen until one's close approach rouses it to flight. In general habits, too, in flight and in nidification this bird of the twilight is almost a counterpart of its European relative.

The next morning awoke me with the sounds of spring-the little alien sparrows outside my window quarrelling over the possession of some disputed nest- 
in," but nidificadecayed e top of d woodsuitable hin was hes deep, he whole hips and

bird the me parts at Whiteds must

onds,

hole flash.

-squirrel, low in a ground ; id naked, risiting it the nest,

gh some wh from 1 cousin, urround. ver seen ht. In ion this ts Euro.

unds of window ed nest. ing-place--and I arose to look upon a day of singular glory, even for this land of clear skies and lovely weather.

The great charioteer of light had already mounted high in the cloudless heavens when I set out, and everywhere I found the splendour and the fulness that go to stamp such a day as this in indelible characters upon the memory. Going down to Three Mile House through fields just awaking to the influence of spring, and laughing with the multitude of song, I saw many birds. Some swallows flew above ine, one the barn swallow, much like that of England but differing in the arrangement of its colours. In the fields were many sparrows, for Nature has endowed the New World with a multitude of these, while man has added yet one species more-the "house sparrow"-and that one now more maligned than all the others put together.

Down in the valley the fields terminated in a wet swamp, beyond which I came into some woodlands. Here it was that a small speck I had been watching resolved itself into a little hawk hovering in the air, sometimes dropping down a iittle, then rising up with a circling flight and again hanging quite stationary except for the slight vibration of its wings, exactly after the manner of our familiar kestrel or "windhover"-to which, indeed, the American sparrow-hawk, as this little falcon is termed, is closely akin. It is in habits and appearance almost an exact counterpart of our kestrel, although much smaller - in fact, scarcely exceeding the size of a thrush, the female (which is the larger) being not more than eleven inches in length. It preys largely upon field-mice, lizards, and various insects, often also upon small birds. The in' 'nortal Wilson mentions having taken from the crop of one of these little hawlis a considerable part of the carcase (including the unbroken feet and claws) of an American robin, although the latter is scarcely smaller than the dashing little freebooter itself! The eggs are laid within hollows and holes high up in the trunls of trees or in the crevices of rocks and cliffs, but seldom is any 
nest constructed. Eggs that I have seen have been quite diminutive, with a creamy or pinkish-white ground marked boldly with reddish-brown and cinnamon colour, chiefly around the larger end, but they vary much in appearance; the average size is given as $I \cdot 36$ by $I \cdot 12$ inclies.

Passing through a little hollow near here my attention was attracted by a sudden outcry among the small birds in the underwood, and next moment out darted another of these little hawks in front of me, its bright reddish lower-back being conspicuous as it flew away, and proving it to be a male.

The warmth and splendour of the day seemed to have aroused to life the whole insect creation, for in the cleared spaces of the woodland grasshoppers stridulated upon every hand, while flies-noxious and innoxiouswere everywhere. Across these little openings, too, came every now and again small troops of a pretty little Polyommatus, or "blue" butterfly, dancing over the ground like a "will-o'-the-wisp," and vanishing down the openings of the woodland. A small Thecla, or " hairstreak," was also not uncommon here, flying close to the ground, and from its small size and dark colour being easily overlooked, especially among the small scrub, like the heathei of an English moor, with which the ground was covered. Once, too, a still-surviving "Camberwell beanty" scurried past me and hastened away over woodland and swamp, while among the underwood I now and again noticed small moths of various kinds upon the wing. Emerging upon the lake by Three Mile House I met with one of our common white butterflies (Pievis rapa) and also saw another shortly afterwards. This butterfly was introduced into the United States about the year I866, but I understand that it was unknown in Nova Scotia for some years after that date, nor does it appear to be very widely distributed there at the present day.

On the I $7^{\text {th }} \mathrm{I}$ visited again the woods running back from the Bedford Basin, but, strange to say, although the day was fine enough there was exceedingly little of 
have been kish-white nd cinna. but they given as

my attenthe small ut darted its bright ew away, eemed to for in the ridulated hoxiousngs, too, etty little over the ng down Thecla, or ing close k colour re small th which iurviving hastened ong the aoths of the lake common another ced into lerstand te years widely

ag back lthough little of interest to be met with. Indeed, spring appeared to be a week or two behind in these great desolate forests as compared with the fields and woodlands adjoining the city. On the outskirts of the forest I noticed a few white-throated sparrows, and also one or two goldencrowned kinglets, while on reaching a little swiftrunning brook I met with a single black-and-white warbler, which attracted my attention by its pleasing little song, which might be syllabled as chiv-vee, chiv-vee, repeated in quick succession. The bird itself frequented the topmost branches of the trees, occasionally creeping upon them or around the trunk in a similar manner to the tree-creeper. As its name implies, this little warbler has the plumage prettily variegated with black and white. This was indeed the only bird of interest met with while in these woods, but in a dense little tract of young firs I found a nest placed against one of the stems at a height of about eight feet, which most probably belonged to the olive-backed thrush, a common enough bird in most parts of Nova Scotia. This nest was shallow and loosely constructed of moss, leaves, twigs, bark strips, \&c., but it contained no eggs.

Fine weather again on the following day took me along the St. Margaret's Bay road, turning off to the right from the head of the North-West Arm, and passing by Chocolate Lake. It was as I neared the latter that I first observed a pair of belted kingfishers, which were circling round and round high above the lake uttering a loud harsh rattling note, and altogether presenting very little resemblance to our English species, which they also considerably exceed in size. I never observed a kingfisher in Nova Scotia during the winter, so that it is evidently a summer visitor to the province. The same may be said in rrgard to the golden-winged woodpecker, one of which I observed on a smaller lake further from the road. My attention was attracted by its loud note, and I soon perceived the bird clinging against the extreme summit of a dead pine on the far side of the lake, at regular intervals giving vent to a sharp and very powerful call note, repeated several 
times in quick succession. It afterwards flew to another tree, settling across a branch instead of on the trunk, and again commencing its cry.

I came across several white-throated sparrows which skulked persistently in the low scrubby growth covering the more open parts of the granite hills, and only announced their presence from time to time by a feeble chirp, ve. $f$ seldom allowing one to obtain a view of them. While wandering over this rocky ground my attention was arrested by a continual tapping at a little distance which I judged to be ocrasioned by a woodpecker at first, but soon found that it proceeded from a little dead stump near at hand, and on making my way to it out flew two chickadees one after the other from a small aperture, there being a little cavity within the stump which the birds had been busy excavating. The habit of burrowing in this species is somewhat interesting, as it shows a close affinity in nesting habits to our burrowing marsh tit, although the bird itself appears to me to be intermediate between our great tit and coal tit.

Another bird that I noticed here was the yellowrumped warbler, which drew my attention to itself by its almost aggressive chant, uttered from the upper branches of a little tree. This song, which was rather loud and sharp, might be syllabled as chi-chi, chi-chi, chi, reiterated with almost vehement persistence. It is a very trim and active little bird, and not at all shy if unalarmed.

In some of the more wooded tracts the little black. throated yellow warbler is common about this time. It is one of the prettiest of the North American " warblers," having the upper plumage of a yellowish-green hue, with a very conspicuous lemon-yellow face and a velvety ulack throat and upper breast, with also bcid black streaks on the flanks. Added to its neat form and tasteful colours it also possesses a pleasing little song, but its ordinary note is a short chirp.

The "white-bill," or black snowbird, breeds commonly in Nova Scotia, but it was not until May 2 I that I succeeded in discovering a nest among the forest-covered 
iv to another the trunk, rows which th covering and only by a feeble a view of ground my $g$ at a little by a wood. ded from a niy way to rom a small the stump

The habit eresting, as ur burrow. rs to me to al tit. he yellowo itself by the upper was rather chi-clii, chi, It is a all shy if

ttle black. ; tiine. It warblers," reen hue, ce and a also bcid form and ittle song,

eeds com. 2 I that I it-covered hills which are always its favourite resort. This nest was in a ragged bank on the roadside, and was placed upon the upper surface of a projecting piece of rock, being well concealed from view by the overhanging turf above. It had a compact exterior wall of grass stalks and fine roots, except at such portion of its circumference as abutted against the bank behind, while within was a neai: and substantial cup of dry grass with a few white horsehairs. I disturbed the female from the nest, which contained four eggs, in appearance of a faint greenisl-white, sparingly marked with small specks of reddish-brown and purplish, and with a ring of spots of the same around the larger end.

One of these mornings going down to the NorthWest Arm I noticed a tree-swallow busily preparing its nest in a tree by the roadside, the site selected being a small hole not more than eight feet from the ground. The mate was meanwhile sitting quietly upon a telegraph wire across the road, quite unalarmed, although apparently eyeing me narrowly from its perch as if in some doubt as to my intentions.

On the road here also I observed one of America's most typical and familiar birds. This was the "ovenbird," a species which has much of the appearance of an Accentor, save that its rich golden crown readily distinguishes it. This individua! alighted in the road near to me, uttering its loud ascending trill from the ground, and when disturbed it merely flew up and settled a little further along the road, recommencing its remarkable chant.

In the wet woods by Chocolate Lake was a wren (Troglodytes hiemalis), very much like our common English species and having a remarkably similar song; also several red-eyed flycatchers, or vireos, birds of curious appearance which frequented the upper branches of trees, uttering from the sheltering foliage a singular song, consisting of a few liquid notes incessantly repeated; but it was hard to recognise in its song the supposed resemblance to the whip-tom-kelly of the familiar olci story. 
Happening one day, this same week, to spend an hour or two on board a vessel moored alongside a quay in the harbour, I amused myself for some time by watching the marine life in the still, clear water around the vessel. The whole surface of the water was teeming with a small animal, appertaining to Medusa, which consisted of an almost transparent whitish disc, less than an inch in diameter, with two retractile filaments which could be extended to the length of five or six inches, and by the alternate extension and retraction of which the animal moved through the water. I also noticed several small whitish Mediusa, and one pink one; these, I observed, moved almost vertically (instead of horizontally) and by regular expansions and contractions of the disc. The wooden piles of the wharf indicated exactly the tidal rise and fall at this part of the world; it was then low water, and I assumed the fall to be about five feet-very different to the tremendous tidal wave which sweeps up the Bay of Fundy, less than a hundred miles away.

On these wooden piles, and above low-water mark, were immense concretions of mussels, but of small size. Below low-water mark the seaweeds grew in profusion, and many forms of marine life could also be seen. inemones were aioundant and of varying sizes, but all were of whitish and brownish hues. Here and there was a starfish, of the forms most common on our own coasts, and deeper down there seemed to be corals or sponges; but there the vision failed, for the light died upon the borders of the depth below and I could see no more.

It was while watching the marvels of this little under. wcrld-so strangely quiet and secluded and so undisturbed by the busy turmoil on the wharf above-that I perceived a long twisting and twining tentacle floating, or rather creeping outward and upward from the forest of seaweed at the side of one of the piles. It was fol. lowed by another, and then I discerned the slimy, tlabby, whitish body of an octopus appear, but only for a moment, as it soon slowly descended again. The 
to spend an side a quay he time by ater around vas teeming which con. c, less than hents which inches, and which the ced several ; these, I of horizon. tions of the ted exactly rld ; it was about five vave which adred miles

ater niark, small size. profusion, , be seen. zes, but all and there in our own corals or light died uld see no

tle under. so undis. re-that I floating, the forest t was fol. he slimy, but only in. The visible tentacles of this individual must have been very nearly two feet in length, so that it was by no means a small one of its kind, and yet far different from the fearful creatures, born of the imagination rather than the reality, which are even now believed in, although still receding from the light of a scientific age. Yet may not such monsters still be lurking all unknown in the gloomy depths of that inexhaustible treasure-house of Nature, which is for evar yielding up its secrets bit by bit, yet all reluctantly, to the curiosity of inquiring man? 
MUST by no means omit to mention one little hawk, which is to be found breeding not so very uncommonly in some parts of Nova Scotia during the spring. This is the sharp-shinned hawk of IVilson - a dashing and interesting little species, and one, moreover, which appears to have less traducers than others of its kindred. There seems, indeed, little in its habits or mode of living, to gain for it human enemies, its prey comprising for the most part small birds, lizards, red squirrels, or the larger kinds of insects. Its flight is more than usually rapid and erratic; its whole mode of action, indeed, being spirited and fierce.

As with other birds of prey, the female bird is the larger in size, being about thirteen inches in total length, while the male is nearly two inches less, and also differs somewhat in plumage.

I have not myself found the nest of the sharp-shinned hawk in Nova Scotia. The bird is described as preferring a cedar swamp for the purpose of nidification, but pine trees are also undoubtedly made use of. The nest is placed at a height varying from ten or fifteen, up to forty feet or more from the ground. It resembles to some extent the nest of our sparrow-hawk (Accipiter uisus), being constructed of sticks, sometimes as much as half an inch in diameter, and neatly lined with small twigs, yet with no softer material than these for the eggs 
to rest upon. These latter are laid during the latter part of May in the United States, but perhaps a week later in Nova Scotia. They are three, four, or five in number, creamy or greyish white as to ground tint, blotched and streaked with purplish-brown, cinnamon and greyish, the average size of an egg being $\mathrm{I} \cdot 48$ by I'Ig inches. The bird, it is said, almost invariably manifests great indignation when the nest is approached, giving vent to loud cries, and yet always keeping at a sufficiently safe distance from the intruder.

Wilson gave this species the somewhat curious name it bears, on account of its having the "edges of the inside of the shins, below the knee, projecting like the edge of a knife, hard and sharp." The tarsus is, of course, intended, and the term "knee" refers to the tarsal joint or ankle. It is strange, it may be remarled, that such a careful and painstaking ornithologist as Alexander Wilson should not have been free from the popular ignorance which still discovers the tibia of a bird in its tarsus, and fails to discern the true "knee," although so very apparent to anyone who will take a dead bird in his hand and make a very cursory examina. tion of its external characteristics.

This lack of acquaintance with anatomy is most lamentable. Few seem to realise to what an extent it can dwarf and confine the mind. There are always to be met many good and capable observers of a grade far removed from the vulgar, yet whose mental vision and reasoning powers are all awry through the want of just a slight study of comparative anatomy. No man or woman can indeed look upon the productions of Nature with any degree of rational understanding unless he or she possesses this slight acquaintance with comparative anatomy, which alone permits the observer to see things intellectually, instead of seeing them with a mere animal vision. 


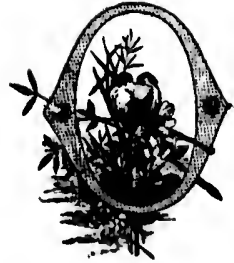

$N$ May 28 Halifax to about 385 northward through and also through a part of Quebec, my destination being situated upon the south shore of the Gulf of St. Lawrence, and being a point of call for the homeward. bound liners from Montreal and Quebec.

The scenery for a great part ot the distan ce consisted of alternating forest, lake arid river, with occasional ranges of wooded hills, and her's and there cabins or fields, and sometimes a consiffrable settlement. The woods were chiefly coniferous, with occasional tracts of birch or other deodiferous trees. Lumbering was progressing in some parts, and once we passed a small river, which was crowded with logs as far as the view extended. The birds most commonly to be observed were crows and American robins. Once I saw a large blue hero:1 reposing quietly among the straggling reeds at the edge of a lake, and frequently snall birds of various species fled on either side into the forest. Horrid, swampy woods were abundant, and here the trees rose from several feet of pestiferous-looking water, filled in every direction with limbs and trunks of trees in every stage of decay, while round about the swamp undergrowth raised itself from the water.
In

port

pare

less

tract

alsc

of $\mathrm{M}$

are

land

of $\mathrm{F}$

A

to er

the

extr

sout

wer

upor

the

a na

$\mathrm{T}$

slow

stat

whi

mou

resic

boas

buil

the

plea

and

of $t$

adjc

gam

Ind

of $t$

cov

ider

and 
In some parts of Nova Scotia and in the adjoining portion of New Brunswick, are very rich tracts of land formed by the alluvial deposit of the streams, and apparently at one time consisting of mud-flats more or less under water. This formation extends over large tracts of land around the head of ti: Bay of Fundy, and alsc around the Petitcodiac, on which stands the town of Moncton. Indeed around the great Basin of Minas, are miles upon miles of mud-flats which would be dry land if it were not for the mighty tidal wave of the Bay of Fundy.

A little before daybreak the next morning we began to enter the rocky region bordering the southern part of the great desolate peninsula of Gaspé, situated in the extreme east of the province of Quebec, and upon the southern side of the Gulf of St. Lawrence. Once we were running for many miles alongside a rapid river, upon the other side of which was a continuous range of the heavily-wooded hills of Gaspé, this stream forming a natural boundary to the vast wilderness beyond.

The morning was well advanced before the train slowed down, and we alighted, stiff and weary, on the station platform in the picturesque little French town which was to mark the first stage of my journey. Rimouski is thoroughly French, there being hardly a resident of British extraction in the place. The town boasts a handsome Roman Catholic cl.urch and other buildings, including a large boys' school or college, under the management of the priesthood. I noticed, with pleasure, that the youths had plenty of outdoor exercise and sport together with military drill, and that in spite of the fact that to-day was Sunday. In an enclosure adjoining an inn, also, several persons were enjoying a game of croquet, while many onlookers stood around. Indeed, the general brightness, cleanliness and prosperity of this little town was apparent on every hand.

The beaches left bare by the receding tide were covered with flocks of shore-birds, amongst which I identified some parties of the white-rumped sandpiper and the red-backed sandpiper, or American dunlin, but 
I could not make ont the species of the majority of the flocks. I also visited the woods in the vicinity of the town but did not observe much of interest.

We left Rimouski in the small hours of the following morning on board the s.s. "Circassian," and during the whole of that day we were ploughing the waters of the mighty Gulf of St. Lawrence.

The morning of the last day in May broke to find us still coasting the length of the vast island of Anticostian unvarying range of hills of no great height, yet with the snow still iying along their summits, to prove the inhospitable and desolate nature of the island. By and by all land faded away, and the gulf widened and stretched away in a great inland sea reaching northward to Newfoundland and the coast of Labrador, and southward to Cape Breton and the shores of Nova Scotia. During the day I observed a great number of little auks, mostly in small parties, although now and again flights of upivards of a hundred of these curious little birds rose from the water and flew round the vessel. The only other birds which came near were a solitary pair of Brunnich's guillemots: a more frequent species here than the rather smaller common guillemot.

As evening came on the rays of the setting sun glittered across the unruffled surface of the water and played in a halo of glory around the rocky heads of St. Pierre and Miquelon lying a few miles away to the nortliward. Between glistened the white sails of one or two fishing boats or small coasting vessels. These two little islets, which dwindled momentarily and passed gradually into the ruddy glow of the fairyland astern, possess a peculiar interest. They are all that remain of the once great North American possessions of France.

We passed Cape Race at five a.m. on June $I$ and were proceeding up the eastern coast of Newfoundland all the morning. Here we passed a great number of icebergs, as many as twenty being in sight at once; nearly all of them, however, had heen driven in-shore, the coast being dotted with them all along, but some few were floating down southward some miles from the 
Jity of the inity of the e following ind during e waters of e to find us Anticostiit, yet with nrove the land. By idened and northward and southova Scotia. little auks, gain flights e birds rose The only ary pair of pecies here

setting sun water and eads of St. vay to the ls of one or These two ind passed ind astern, t remain of f France. une I and ivfoundland number of it at once ; in in-shore, , but some es from the coast, and these necessitated constant attention on the part of those in charge of the vessel. The bergs were of every imaginable form and size. One was roughly in the form of a pyrninid with the apex broken off, the height from the water-line being nearly three times as much as the breadth.

Nost of the larger icebergs evidently consisted of masses detached from the solid ice-field, and these floated in a variety of inclinations; one ur two rode in their former horizontal position, but the majority were inclined to one side or another, and some so much so that they presented roughly a "house-top" shape, the original surface constituting one slope and one of the fractured sides the other. On some of the ledges of these masses the sea-birds could be seen congregated in hundreds upon hundreds. The largest berg of all, however, was seen shortly before we entered the harbour of St. John's. It was an immense block, roughly oblong in shape, from the mass of an ice-field, and was Hoating nearly in its original position, its surface being worn by furrows and corrugations, and much soiled from some cause. The surface of the mass was estimated to be at least an acre in extent; it projected a considerable height from the water, and as all icebergs have twothirds of their mass below the surface, and only onethird above, the weight of this huge block must have been truly prodigious. The beautifully pinnacled and turreted icebergs common further southward are rare so far north as this, where the sun and ocean lack the warmth necessary to fashion such picturesque and beautiful architecture from these rough-hewn unwieldy blocks.

Among the birds frequenting the coast I noticed several great black-baclied gulls, American herring-gulls and kittiwakes, and also a solitary Iceland gull (one of the white-winged group) just on entering the harbour of St. John's. About the fishing-grounds were many greater shearwaters, which were usually to be observed in parties, sometimes as many as fifty in number; they frequently settled upon the surface of the water and sometimes dived. 
We wourable passage from St. John's, but up to the irterest is ve orded. In the mid-Atlantic the only birds I noticed we e some few of the small, black, white-rumped petrels, including the Leach's, Wilson's, and stormy petrels, which are comnonly known as "Mother Cary's chickens," and a small number of grea.ter shearwaters, with which were, I believe, one or two of the less known "dark-bodied" shearwaters, which were until recently thought to be the young of the last mentioned species. There were also a fair number of fulmars, among which were several of the dark phase, which variety or race has those parts which are normally white of a deepish grey.

O1. June 7 we were off the north-west coast of Ireland, and bird-life was more abundant, although not of great variety. The fulmars were still with us in some numbers, but there were none of the dark phase which I had noticed some few days before. There were also here a few black-backed, herring and other gulls, one pair of gannets, and numbers of puffins, guillemots and other diving birds which were usually observed in parties of varying magnitude.

As we entered the approach to Lough Foyle we were much struck by the beautiful and picturesque scenery, superior, I thought, to almost anything to be seen on the other side of the water. The hillsides were green with the greenest of well-tended fields, and above these the hills, green to the very summit, seemed to assert the peculiar aptness of the epithet "Emerald Isle." Through the fields wound white and tiresome-looking roads, while here and there were dotted the characteristic cabins of the peasantry, who were summoned to their doors by the report of our rockets and stood there waving handkerchiefs and aprons to welcome home again countrymen, or, perhaps, relations. Down by the water were the residences of the more wealthy ciasses, and here, too, we passed a small but picturesque ruin which instantly became an objest of interest to our amateur photographer. Soon, however, we were lying-to 
in Lough Foyle itself, which extended before us for miles, its glassy surface glittering like burnished silver in the rays of the declining sun, and its unruffled expanse broken only by one or two motionless "ruall craft. After a far too limited stay at this inter. stir. spot, however, we were once more on our way to $c$.' England.

IVe passid the Manxmen's shores at an early hour the next morning, and before $8 \mathrm{a} . \mathrm{m}$. were steamis $r$ up the Mersey in the midst of a characteristicr.'ly dense fog, which, however, lifted sufficiently for us co catch a glimpse of New Brighton as we passed; while in a few minutes more we were lying-to off the docks at Liverpool. Then came the disembarking, the ordeal of the custom-house, and the bustle of the railway station, breaking up the glamour of solitude as a dream dies at daybreak, and speeding us back along one of those great veins to be re-energised in this great throbbing heart which is for ever pulsing forth its arteries into the most distant regions of the earth!

we were scenery, e seen on ere green ove these to assert ald Isle." e-looking acteristic 1 to their here wavme again by the ciasses, que ruin st to our e lying-to 


\section{APPENDIX.}

THE following is a systematic list of the species of North American birds mentioned in the foregoing pages, the prefixed numbers and the nomenclature being in accordance with the check list issued by the American Ornithologists' Union, and the square-bracketed synonyms being those more usually employed by British ornithologists. Round brackets indicate that the name is not that given by the original describer. The list is not intended as a complete list of Nova Scotian birds, there being many species occurring in the province which have not been mentioned in the present work.

Marked * are species which also occur in Great Britain.

Marked + are racial varieties of species which occur in Britain.

\section{Pidilymbus podiceps (Linn.), Pied-billed GREBE.}

7. *Urinator imber (Gunn), Loon. [Colymbus glacialis, Linn., Great Northern Diver.]

I1. "Urinator lumme (Gunn), Red-throated LooN. [Coly'mbus septcotrionalis, Linn., Red-throated Diver.]

13. "Fratercula arctica (Linn.), PuFrin.

27. "Cepphus grylle (Linn.), Black Guillemot. [Uria grylle.].

30. *Uria troile (Lirn.), Murre. [Common Guille. mot.]

31. "Uria lomvia (Linn.), Brunnich's Murre. [Uria bruenuichi, E. Sabine, Brunnich's Guillemot.] 
34. "Alle alle (Linn.), Dovekie. [Mergulus alle (Linn.), Little Auk.]

38. *Stercorarius longicaudus, Vieill., LonG-TAILED JAEGER. [Stercorarius parasiticus (Linn.), Longtailed Skua ; Buffon's Skua. Note.-The $S$. parasiticus of the A.O.U. list is the Arctic or Richardson's Skua, S. crepidatus of British ornithologists.]

40. *Rissa tridactyla (Linn.), Kittiwake.

43. "Larus leucopterus, Faber, Iceland Gull.

47. "Larus marinus, Linn., Great Black-BaCked GuLL.

5Ia. Larus argentatus smithsonianus, Coues, AMERICan Herring Gull. [Larus argentatus; the American form not considered distinct by British ornithologists.]

86. *Fulmarus glacialis (Linn.), Fulmar.

89. *Puffinus major, Faber, Greater Shearwater.

95. *Puffinus griseus (Gmel.), Dark-Bodied ShearWATER. [Sooty Shearwater.]

104. *Procellaria pelagica, Linn., Stormy Petrel.

I06. *Oceanodroma leucorhoa (Vieill.), LEACH's Petrel. [C $y^{\prime}$ mochorea leniorrhoa (Vieill.), Forktailed Petrel.]

rog. *Oceanites oceanicus (Kuhl), Wilson's Petrel.

I 17 . *Sula bassana (Linn.), GanNeT.

155. "Histrionicus histrionicus (Linn.), HaRLEQUiN Duck. [Casmonetta histrionica (Linn.); Histrionicus minutus (Linn.)]

172. Branta canadensis (Linn.), Canada Goose. [Bernicla canadensis (Linn.).]

194. Ardea herodias, Lirn., Great Blue Hron.

240. *Tringa fuscicollis, Vieill., WhIte-RUMPED SANDPIPER. [Bonaparte's Sanclpiper.]

243a.tTringa alpina pacifica (Coues), RED-BACKED SANDPIPER. TAmerican Dunlin ; doubisully distinct from Tringa alpina.]

263. Aotitis macularia (Liñ.), Spotted Sandpiper. [Totamus macularius (Linn.)]

298. Dendragapus canadensis (Linn.), Canada Grouse. [Spruce Partridge.] 
300a. Bonasa umbellus togata (Linn.), Canadian RufFed Grouse. [Canadian birds are said to constitute a darker race than the type, $B$. umbellus.]

331. Circus hudsonius (Linn.), Marsh Hawk.

332. Accipiter yelox (Wils.), Sharpshinned Hawk.

334. Accipiter atricapillus (Wils.), American GosHAwK. [Astur atricapillus (Wils.).]

339. Buteo lineatus (Gmel.), Red-shouldered Hawk.

352. Haliætus leucocephalus (Linn.), BALD EAGLE.

360. Falco sparyerius, Linn., American SparrowHAWK.

364. TPandion haliætus carolinensis (Gmel.), AMERICAN OSPrex. [Pandion haliatus (Linn.); the separation of the American bird is not recognised by British ornithologists.]

368. Syrnium nebulosum (Forst.), Barred OwL. [Strix nebulosa of Forster.]

370. Ulula cinerea (Gmel.), Great Gray Owl.

372. Nyctala acadica (Gmel.), Saw-whet Owl.

375. Bubo yirginianus (Gmel.), Grea - Horned Owl.

376. *Nyctea riyctea (Linn.), SNowy (TwL. [Nyctea scani.iaca (I.inn.. . .

390. Ceryla alcyon (Linn.), Belted Kincifisher.

394. Dryobates pubescens (Linn.), Driwny WoodPECKER. [Picus pubescens of Linnæus.]

4I2. Colaptes auratus (Linn.), Ficker. [Goldenwinged Woodpecker.]

420. Chordeiles virginianus (Gmel.), Night-hawk.

428. Trochilus colubris, Linn., RubY-Throated HumMING BIRD.

474. *Otocoris alpestris (Linn.), HoRned LaRk. [Shore Lark.]

477. Cyanooitta cristata (Linn.), Blue Jay.

484. Perisoreus canadensis (Linn.), Canada Jay.

486. tCoryus corax principalis, Ridgw., Northern Raves. [This race was described since the publication of the A.O.U. list, in which No. 486 is called "American Raven".]

488. Coryus americanus, Aud., American Crow. 
ANADIAN re said type, $B$.

LAWK. N Gos.

HAwk. AGLE. ARROIVAMERI.); the t recog-

Owx.

D OwL. [Nyctea

ER.

WOOD-

Folden.

AWk. HUM-

LARK.

Y

THERN ce the :h No.
515. Pinicola enucleator canadensis (Cab.), A.MerICAN Pine Grosbeak. [Pyrrluula enucleator (Linn.); n-1 ish ornithologists do not recognise the separailun of the American bird.]

- *Passer domesticus (Linn.), European House SPARROW. [Introduced.]

534. *Plectrophenax nixalis (Linn.), SNowflake. [Snow Bunting.]

558. Zonotrichia albicollis (Gmel.), White-throated SPARROW.

56o. Spizella socialis (Wils.), Chipping Sparrow.

567. Junco hyemalis (Linn.), Slate-Colored Junco. [Black Snowbird.]

585. Passerella iliaca (Merr.), Fox Sparrow.

6I 3. Chelidon erythrogaster (Bodd.), Barn Swallow. [Hirundo horreornm (Bodd.).]

61. Tachycincta bicolor (Vieill.), Tree Swallow. [White-bellied Swallow.]

621. Lanius borealis (Vieill.), Northern Shrike.

624. Yireo oliyaceus (Linn.), Red-eyed Vireo. [Redeyed Flycatcher.]

636. Mniotilta yaria (Linn.), Black and White Warbler.

655. Dondroica coronata (Linn.), Myrtle Warbler. [Yellow-rumped Warbler.]

667. Dendroica virens (Gmel.), Black-throated GreEN Warbler.

671. Dendroica vigorsii (Aud.), Pine Warbler. iDendraca pinus of Baird; Pine-creeping Warbler.]

674. Seiurus aurocapillus (Linn.), Oven-Bird. [Golden crowned Thrush.]

697. Anthus pensilyanicus (Lath.), American Pipit. [Anthus ludovicianus of Lichtenstein.]

722. Troglodytes hiemalis, Vieill., Winter W $W^{\prime}$ REN.

726. TCerthia familiaris americana (Bonap.), BRown Creeper.

727. Sitta carolinensis, Lath., White-breasted NutHATCH.

728. Sitta canadensis, Linn., Red-Breasted NutHATCH. 
735. Parus atricapillus, Linn., Chickadee. [Blackcapped Chickadee. 7

740. Parus hudsonicus, Foist., Hudsonian ChickADEE.

748 Regulus satrapa, Licht., Golden-crowned KingLET.

758a. Turdus ustulatus swainsonii (Cab.), OliveBaCKed Thrush.

759b. Turdus aonalaschkæ pallasii (Cab.), HERMIT Thrush.

76r. Merula migratoria (Linn.), American Robin. [Tuvdus migratorius, Linn., Migratory Thrush.] 
Advertisements.

Black -

CHICK-

KING.

Olive-

Hermit

Robin. arush.]

To be published in the Autumn of 1895 , or as soon as the first 250 orders have been received.

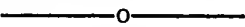

Fcap. 8vo, boards, price $\mathrm{I} /$-. Also cloth, rilt lettered, printed on fine paper, price $2 /-$.

\section{A CONCISE HANDBOOK}

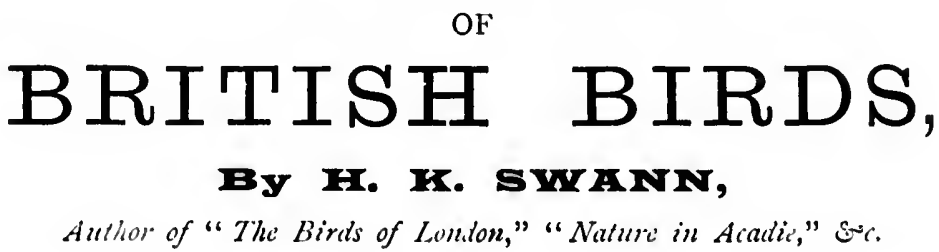

The want of a cheap, concise and reliable handbook of British Birds has long been apparent, almost all the stanciart works on the subject being so high-priced as to be beyond the reach of the great majority of birdlovers or students. It is to supply this want that the present handbook will be published. It will be wy far the most useful book on British Birds ever offered to the public at the price. The book will, in fact, prove invalu. able as a handy text-book for reference.

Every species of birl occurring in the British Islands will be included; a concise and careful account leing given of the clistribution and habits of each, logether with accurate measurements of the lird and descriptions of its plumage at all ages and seasons, especial care being taken to render the information sufficient for the identification of any species without difficulty hy a reference to the handlbook. Particular attention will also be paid to the niditication of those species found breeding in the British Islands, the descriptions of their neste and eggs being such as will he of practical service for the purpose of identification.

The book will le sent to press as soon as 250 orders have been received. Those wishing (1) subscribe are therefore desired to communicate their willingness to the Author, 10, IIarrington Street, Regent's Park, London. Remittances should not he sent until the hook is receivel. 
Advertisements.

Cloth, 8vo, pp. xv., 136, price $2 /-$, by post $2 / 2$.

\section{. \\ THE BIRDS OF LONDON, \\ By H. K. SWANN.}

"Even the hardened ornithologist may be surprised to learn that over 200 varieties of birds make their appearance periodically in and around our begrimed city. Yet such, Mr. Swann tells us, is the case, and in this very useful little work he not only gives the list, but tells us where and when each kind may be found. To those who have hitherto thought that the sparrow, the bullfinch, the starling and perhaps a dozen other birds, were our only feathered visitors, the book will come as a revelation."Sicnce Siftings.

"'The Birds of London' is a capital book, and we earnestly recon. mend it to those wise men and women whose earliest breakfast is the fresh air of the meadows."-Literary Worla.

"The introduction is specially noticenlle for its simplicity of diction; at the same time it betrays its author as an old hand in the ornithological sphere and not without an eye for the asthetic in Nature. "-Naturalists" Journal.

"It is a convenient little volume, and can be carried easily in the pocket by anyone who rambles about London suburlss in search of birds."Nature Notes.

"The book--to local ornithologists-should prove most invalualle. It is elieap, correct, of handy form, and well got up. There is no excuse for any ornithologist residing in or near Lonclon not possessing the work. For the benefit of these we may mention that Howard Saunders has been fol. lowerl in the classification, Sc., and that the introduction describes all the best local biril districts with much accurncy." - Nature Lover.

Post free 2/2 from the Author, 10, Harrington Street, Regent's Park, London. 
THE

\section{NATURALISTS' JOURNAL:}

\section{$\mathfrak{A}$ Sibagasine of Ihatural science.}

Edited by A. FORD and S. L. MOSLEY, F.E.S., Assisted by a Staff of Specialists.

that over and around and in this where and hought that ther birls, elation."-

stly recom. is the fresh

of diction ; ithological Vaturalists"

the pocket birds." -

luable. It excuse for work. For $s$ been fol. bes all the

\section{Street,}

\section{LINDON :}

ELL_OT S'TOCK, 62, Paternoster Row, E.C. 
In one 4 to volume, silk cloth, gilt top, uncut edges, $E_{\mathrm{I}}$ IIs. 6d.

\section{METHODS in the Art of TAXIDERMY,}

BY OIIYER DAYIE,

Author of "Nests and Eggrs of North Amerian Birds," Scc.

"Containing ninety full-page Engravings, over five hundred figures minutely illustrating the nost practical methods practised in the ar:. It teaches in detail, step by step, the skinning and stuffing of birds, mammals, crustaceans, fishes and reptiles, together with illustratious of forms ancl attitudes of the animal kingdom. The text is by OLrvis Idivie, who has made Taxidermy his life study and profession. . . . The illus. trations were drawn by the eminent Bird and Mammal Artist, Theodure Jasper, A.M., M.D., whose experience in the art of Taxidermy extends vier a period of fifty years. . . . Among these engravings are included reproductions from photographs of actual work by American Taxidermists."

Copies of this magnificent work (prlce £1 11s. 6d., carriage paid) may be had from H. K. SWA Park, London.

Price 3s. 6d., cr. 8vo, cloth, gilt lettered, with frontispiece. Edition limited to 250 copies.

\section{NATURE IN ACADIE,}

BY H. K. SWANN, Aluthor of "The Birt's of London," sce.

To those who delight in the study and olservation of Nature, this low: the account of the voynge of a Naturalist to Nova Scotia, will he ac. ceptable; to the Nature-lover as well as the Naturalist, for the work is essentially a record f observations of birds, animals, insects and the many torms of life with waich Nature has enriche? the vast region of forest, lake 2ul 11, nutain, known as Enstern Canaln. The descriptive portions of the look pictur: vividly the aspect and denizens of the great primeval wilderness, while the Appendix provides a systematic list of the lirds "nisped in the work, the nomenclature nccorting with that of the "sheck list" issued hy the American Ornithologists' Union.

Copies, price 3s. 6d., post free, may be obtained from the Author, 10, Harrington Street, Regont's Park, London. 

